Quantitative Political Economy Research Group

Department of Political Economy

King's College London

\title{
QPE
}

\section{COVID-19 and people's health-wealth preferences: Information effects and policy implications}

QPE Working Paper 2020-5

Shaun Hargreaves Heap

Christel Koop

Konstantinos Matakos

Asli Unan

Nina Weber

May 19, 2020 


\title{
COVID-19 and people's health-wealth preferences: information effects and policy implications
}

\author{
Shaun Hargreaves Heap*, Christel Koop*, Konstantinos Matakos*, \\ Asli Unan, Nina Weber*
}

May 19, 2020

\begin{abstract}
Policy makers responding to COVID-19 need to know people's relative valuation of health over wealth. Loosening and tightening lockdowns moves a society along a (perceived) health-wealth trade-off and the associated changes have to accord with the public's relative valuation of health and wealth for maximum compliance. In our survey experiment $(\mathrm{N}=4,618)$, we randomize information provision on economic and health costs to assess public preferences over this trade-off in the UK and the US. People strongly prioritize health over wealth, but the treatment effects suggest these priorities will change as experience of COVID-19 deaths and income losses evolves. Information also has heterogeneous/polarizing effects. These results encourage policy caution. Individual differences in health-wealth valuation highlight this study's importance because they map onto compliance with current lockdown measures.
\end{abstract}

Keywords: Covid-19, health-wealth trade-off, information, value of life, lockdown, policy compliance

JEL Codes: C90, D78, D84, D91, H12, I12, J17

${ }^{*}$ Department of Political Economy, King's College London, London WC2B 4BG, UK. Correspondence to: shaun.hargreaves_heap@kcl.ac.uk. The data collection benefitted from a grant from the King's Together Seed Fund. All authors contributed equally to the study. 
At the onset of the COVID-19 pandemic and in the absence of medicine-based responses, policy makers had to rely on behavioral interventions to slow the spread of the virus [1. They restricted individual freedom in many countries to prevent deaths through the transmission of Covid-19. The reduction in deaths came, however, with an economic cost: the lockdown restricted economic activity and led to falling output and income [2]. In effect, policy makers opted for health over wealth in what was a health-wealth trade-off at the beginning of the pandemic. They now face a similar trade-off over how quickly and comprehensively to loosen the lockdown. The quicker and more complete, the stronger the initial economic recovery but also the greater the risk that COVID-19 deaths will increase again. Indeed, such trade-offs are likely to be a recurring feature of the foreseeable future until medicine-based responses are developed. When deciding where to position on such (perceived) trade-offs, policy makers need to take account of the extent to which people think health matters more than wealth. This is not just for the politics of these decisions but also for their efficacy: people tend to comply with policies they agree with [3]. Policy makers also need to know how such valuations might change as events unfold. For these reasons, it is important to understand the public's current valuation of health versus wealth and how this might change with new information. This paper reports on a survey experiment designed to address these questions in a representative sample of the UK and the US.

The survey consists of a sequence of binary choices between pairs of health and wealth outcomes. Figure 1 shows the actual sequence of eight decisions between these pairs given to UK and US respondents. If a person values both life and income and has a preference ordering [4] over their various combinations, they should choose option A in Decision 1 and option B in Decision 8. This is because, in Decision 1, A dominates B in both the health and wealth outcomes, whereas in Decision 8, B weakly dominates A as both have the same death outcome, but B is better on income loss. In the intermediate Decisions 2-7, option A has the better health outcome and option B has the better wealth outcome. As subjects move through Decisions 2-7, the health advantage of A over option B becomes progressively 
smaller in terms of death avoided per unit of income lost. In this way, a person with a preference ordering will switch from option A to B as they progress through Decisions 1-8. Where they switch indicates how strongly they prioritize health over wealth: the later the switch, the stronger the preference for health over wealth [5], 6].

Figure 1: Decisions for preference elicitation

\begin{tabular}{|c|c|c|c|c|}
\hline & \multicolumn{2}{|c|}{ United Kingdom } & \multicolumn{2}{|c|}{ United States } \\
\hline & Option A & Option B & Option A & Option B \\
\hline Decision 1 & $\begin{array}{l}445 \text { lives lost per million, } f 2,700 \\
\text { average disposable income loss }\end{array}$ & $\begin{array}{l}460 \text { lives lost per million, } f 2,750 \\
\text { average disposable income loss }\end{array}$ & $\begin{array}{l}320 \text { lives lost per million, } \$ 4,000 \\
\text { average disposable income loss }\end{array}$ & $\begin{array}{l}335 \text { lives lost per million, } \$ 4,150 \\
\text { average disposable income loss }\end{array}$ \\
\hline Decision 2 & $\begin{array}{l}412 \text { lives lost per million, } f 2,500 \\
\text { average disposable income loss }\end{array}$ & $\begin{array}{l}431 \text { lives lost per million, f2,420 } \\
\text { average disposable income loss }\end{array}$ & $\begin{array}{l}310 \text { lives lost per million, } \$ 3,850 \\
\text { average disposable income loss }\end{array}$ & $\begin{array}{l}325 \text { lives lost per million, } \$ 3,740 \\
\text { average disposable income loss }\end{array}$ \\
\hline Decision 3 & $\begin{array}{l}383 \text { lives lost per million, } f 2,300 \\
\text { average disposable income loss }\end{array}$ & $\begin{array}{l}393 \text { lives lost per million, } f 2,200 \\
\text { average disposable income loss }\end{array}$ & $\begin{array}{l}247 \text { lives lost per million, } \$ 3,670 \\
\text { average disposable income loss }\end{array}$ & $\begin{array}{l}256 \text { lives lost per million, } \$ 3,500 \\
\text { average disposable income loss }\end{array}$ \\
\hline Decision 4 & $\begin{array}{l}360 \text { lives lost per million, f2,150 } \\
\text { average disposable income loss }\end{array}$ & $\begin{array}{l}367 \text { lives lost per million, } f 2,020 \\
\text { average disposable income loss }\end{array}$ & $\begin{array}{l}213 \text { lives lost per million, } \$ 3,500 \\
\text { average disposable income loss }\end{array}$ & $\begin{array}{l}219 \text { lives lost per million, } \$ 3,300 \\
\text { average disposable income loss }\end{array}$ \\
\hline Decision 5 & $\begin{array}{l}300 \text { lives lost per million, } f 2,000 \\
\text { average disposable income loss }\end{array}$ & $\begin{array}{l}305 \text { lives lost per million, } f 1,850 \\
\text { average disposable income loss }\end{array}$ & $\begin{array}{l}200 \text { lives lost per million, } \$ 3,300 \\
\text { average disposable income loss }\end{array}$ & $\begin{array}{l}204 \text { lives lost per million, } \$ 3,100 \\
\text { average disposable income loss }\end{array}$ \\
\hline Decision 6 & $\begin{array}{l}240 \text { lives lost per million, } f 1,900 \\
\text { average disposable income loss }\end{array}$ & $\begin{array}{l}243 \text { lives lost per million, } f 1,750 \\
\text { average disposable income loss }\end{array}$ & $\begin{array}{l}188 \text { lives lost per million, } \$ 3,120 \\
\text { average disposable income loss }\end{array}$ & $\begin{array}{l}192 \text { lives lost per million, } \$ 2,820 \\
\text { average disposable income loss }\end{array}$ \\
\hline Decision 7 & $\begin{array}{l}230 \text { lives lost per million, } f 1,800 \\
\text { average disposable income loss }\end{array}$ & $\begin{array}{l}232 \text { lives lost per million, } f 1,640 \\
\text { average disposable income loss }\end{array}$ & $\begin{array}{l}177 \text { lives lost per million, } \$ 2,350 \\
\text { average disposable income loss }\end{array}$ & $\begin{array}{l}180 \text { lives lost per million, } \$ 2,000 \\
\text { average disposable income loss }\end{array}$ \\
\hline Decision 8 & $\begin{array}{l}210 \text { lives lost per million, } f 1,550 \\
\text { average disposable income loss }\end{array}$ & $\begin{array}{l}210 \text { lives lost per million, } f 1,450 \\
\text { average disposable income loss }\end{array}$ & $\begin{array}{l}165 \text { lives lost per million, } \$ 1,950 \\
\text { average disposable income loss }\end{array}$ & $\begin{array}{l}165 \text { lives lost per million, } \$ 1,800 \\
\text { average disposable income loss }\end{array}$ \\
\hline
\end{tabular}

The experimental element of the survey comes from our test of the stability of these revealed preferences for health versus wealth. We asked respondents to make these decisions a second time. After the first round of these decisions, they engaged in an unrelated task and answered questions regarding their likely estimates of COVID-19 deaths and income loss given the current lockdown. They were then divided randomly into 3 sub-groups and, before the second round of decisions, one sub-group received information about predicted COVID19 deaths and another received information on predicted income losses due to COVID-19 mitigation measures. The final sub-group was our control and they heard a short piece of instrumental music instead of information. If individuals change how they prioritize health over wealth in one or both information treatments, this suggests priorities will change in certain predictable ways as the experience of death and economic loss unfolds in the coming 
weeks and months. In so far as there are no treatment effects and individuals do not change their revealed priorities significantly between the first and second round, the results point to stability in priorities in the face of changing information.

Finally, we asked a series of demographic and attitudinal questions. This enabled us to assess whether individual compliance with current lockdown measures is indeed predicted by individual differences in the valuation of health over wealth. We also tested for what individual objective characteristics (e.g., age and income) and subjective ones (e.g., risk tolerance and their perception of the threat of COVID-19) help predict these individual differences in the valuation of health versus wealth.

The survey was conducted between Friday 17 and Tuesday 21 April 2020: at the end of the week when both the UK and the US were predicted to hit peak deaths [7], [8]. 2385 and 2233 respondents participated in the UK and the US respectively. The survey was conducted using Prolific Academic and was pre-registered with EGAP [9]. We present full details on sampling, the survey instrument and our estimation strategy in SM (section S1 and S4).

Figure 2 reports on the distribution of switch points in the UK and the US for those switching only once in both the first and the second round, disaggregated by treatment and control. The majority in both countries switch at Decision 8 in both rounds, indicating a very high valuation of health over wealth for the majority. Based on such high valuations, the original lockdown measures, that may have saved several hundred thousand lives in both countries at the loss of perhaps as much as 10\% of GDP, were consistent with the public's preferences for health over wealth. This, in turn, fits with the high trust and approval ratings that governments enjoyed when the lockdown measures were introduced [10]. However, if these high valuations remain [11], policy makers have a daunting task in calibrating the relaxation of the lockdown. If the relaxation is accompanied by relatively modest increases in deaths, then it will not be popular with the majority of the population in both countries, even if it restores income losses. Therefore, it is important to assess this interpretation of the survey results and the likely stability of this apparent high valuation of health over wealth. 
This is what we do next.

Figure 2: Percentage of those who switch once, by decision switch point

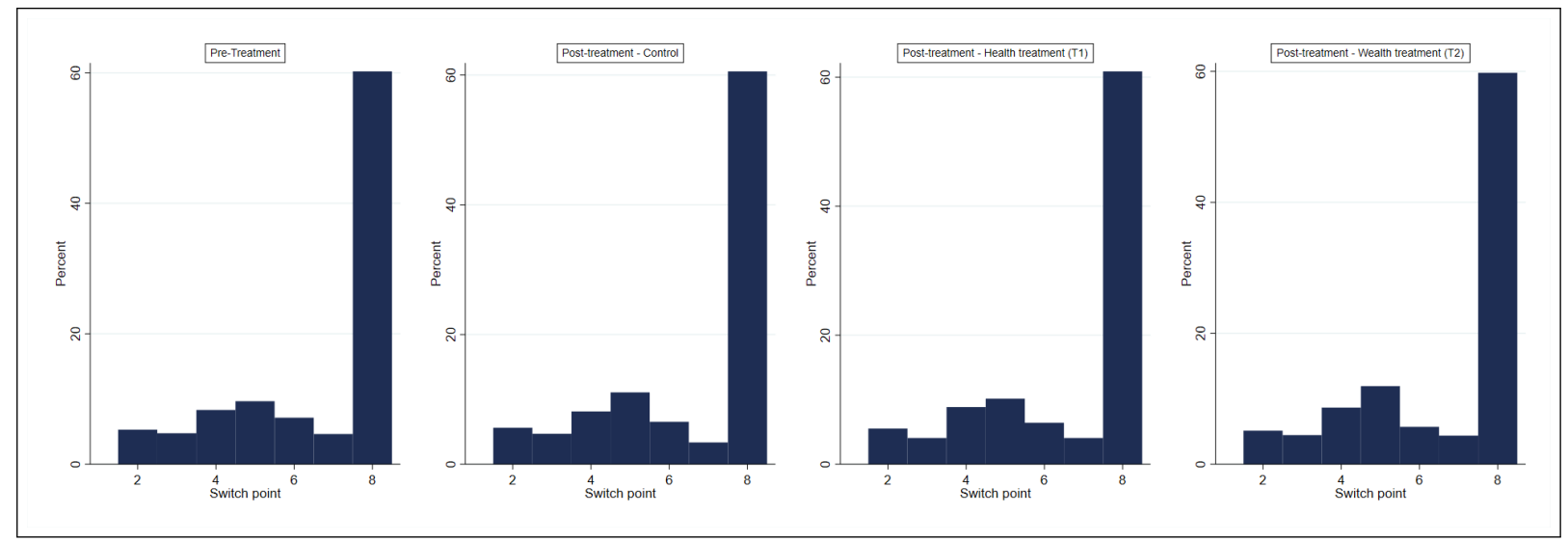

On the interpretation of the evidence, a high valuation of health over wealth comes from the analysis of those who had a single switch point and so behaved in a manner consistent with having a preference ordering. This was the case for most observations: $75 \%$ fall into this category. $15 \%$ showed multiple switch points; hence, though revealing a preference in their individual decisions, these decisions do not cohere to form a preference ordering over health and wealth. Such a proportion is typical [4. The remaining subjects have no switch points: respondents either always chose A, favoring health independently of the wealth consequences (9\%), or always B (1\%). The preponderance in this group of non-switchers of those who have a strict preference for health, whatever the wealth cost, reinforces the conclusion that health is highly valued over wealth.

On the stability of this high valuation, we first analyzed the constancy of individual behavior in the control group across the two rounds decisions are made (SM, section S3a). Although some respondents change their switch point, most people in the control group plausibly exhibit a stable preference ordering across the two rounds. With this result for the control group, we now turn to the possible treatment effects. We examined whether the changes in respondents' switch point between the two rounds are significantly different in either of the treatments as compared to the changes observed in the control group. The 
changes in switch point are, importantly, within-subject and we therefore make comparisons between-subjects in a treatment and the control group with treatment dummies in the regressions in Figures 34 (also see SM section S2b-c).

We have three treatment effects to report. First, an unconditional COVID-19 death information treatment effect in the UK: there is a significant increase in the number of subjects who switch from having a single switch point on the first occasion to always choosing option A (see Panel A in Figure 3). That is, they shift from having a preference ordering over health and wealth to a strict preference for health, whatever its wealth cost.

Second, Panel B in Figure 3 shows a significant conditional treatment effect in both the US and the UK. Those in the income loss information treatment group who learned that they underestimated the income loss are significantly more likely to move down from the Decision 8 switch point. $60 \%$ of the population switch at Decision 8 and $28 \%$ underestimated the income loss. These effects are very robust: they are supported by the between subject analysis when comparing across the two treatment groups and the control (we report ATEs in SM, section S3f). The last two plots in Panel B suggest that this treatment effect, however, does not occur throughout the range of possible switch points (i.e., for the other $40 \%$ of this group).

These two treatment effects suggest that people's relative valuation of health over wealth will change in predictable ways as the experience of death and income loss unfolds. In particular, the longer the lockdown in both countries, the bigger the income losses and the less likely are these losses to have been anticipated, leading to a reduction of the high relative valuation of health over wealth. This has important policy implications. The public will likely become more willing to countenance increases in deaths as the lockdown is relaxed, the later and the slower is the loosening. This message is reinforced in the UK where this valuation is likely to tilt in the opposite direction if COVID-19 deaths are salient, which is more likely under an earlier relaxation of the lockdown.

The third treatment effect can be seen in the second plot of Panel B. It is conditional 
Figure 3: Treatment effects

\section{Panel A}
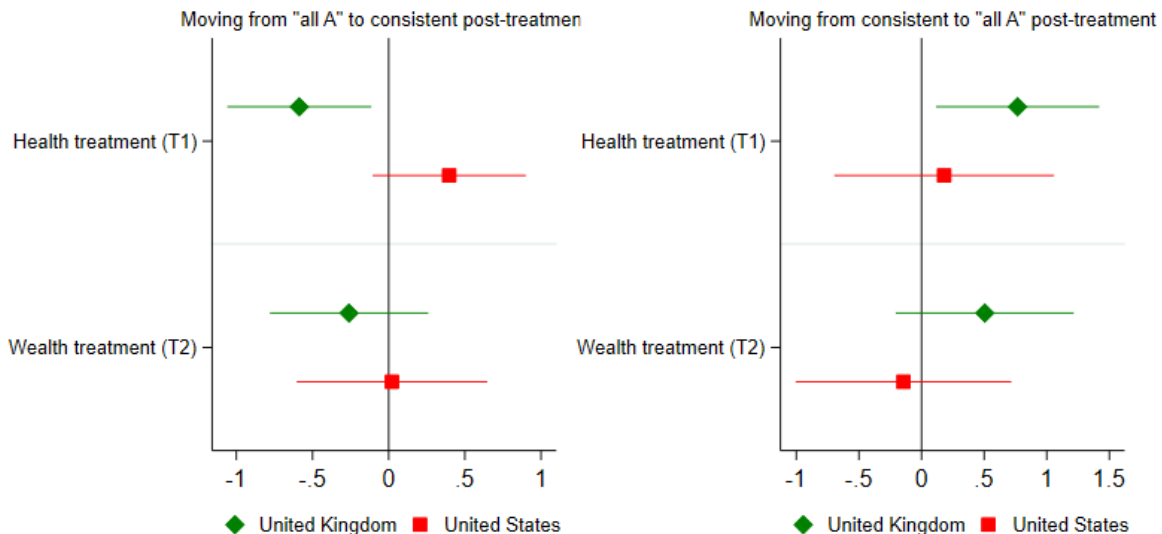

Panel B
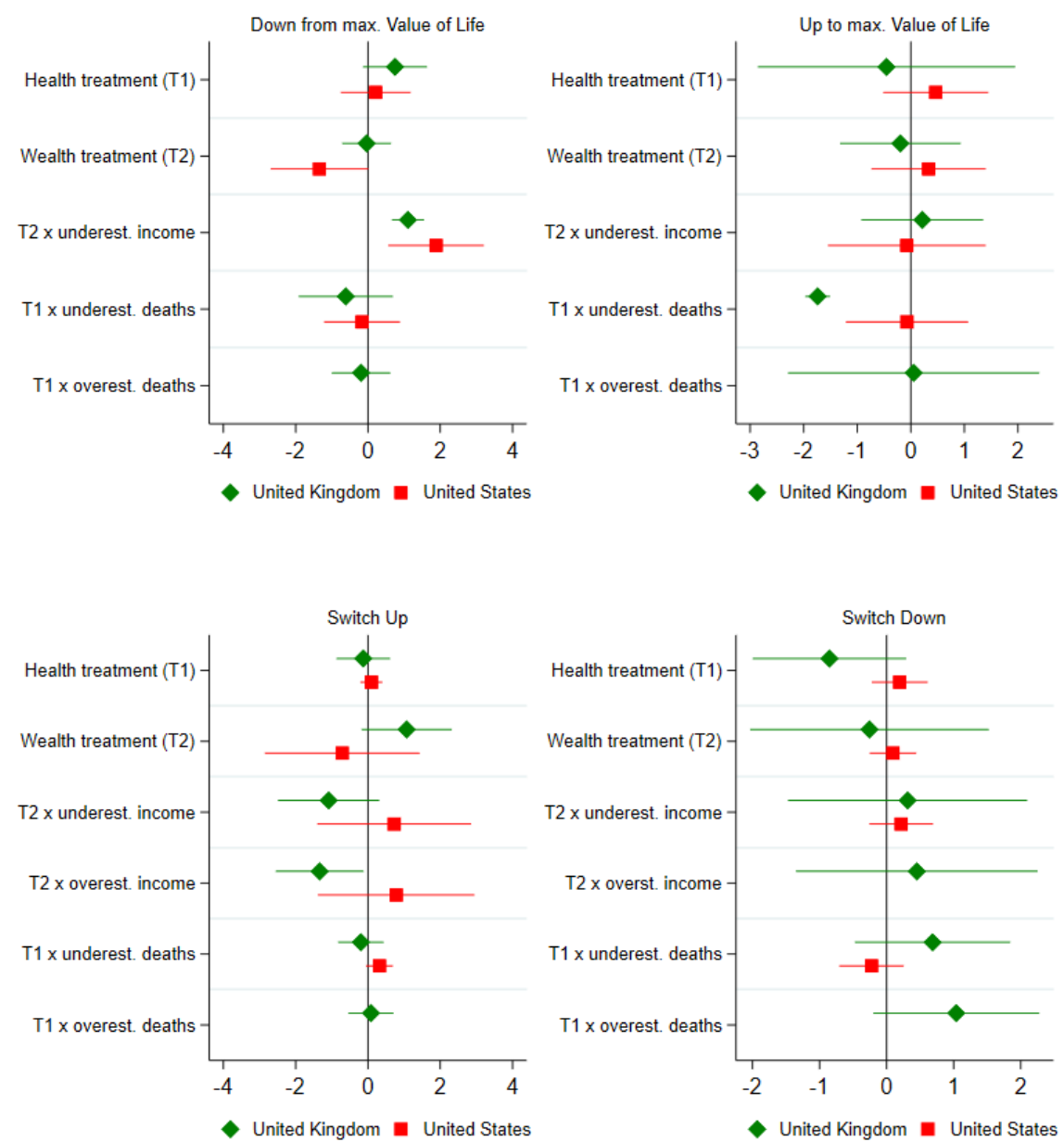
and qualifies the first effect for those who underestimate COVID-19 deaths in the death information treatment of the UK. Those who underestimate go in the opposite direction to the general treatment effect: they are less likely to move up to the maximum relative valuation of health over wealth than in the control group. Examining the possible reasons for this, we find that it is associated with individual respect for authority (SM, section S2e). Those who have less respect for authority are, it seems, more likely to react perversely to the death information by becoming less likely to value health relative to wealth so highly. It is 'as if' they respond to information about the death toll being worse than anticipated by 'refusing' to update and decide instead that lives matter less: an informational backlash. This treatment effect - together with the first one - has the important implication that unexpected deaths will polarize the UK public: death information generally increases the valuation of health, but the reverse is true for those who underestimate the deaths.

Finally, in Figure 4, we present the regression results testing whether individual differences in the valuation of health versus wealth are likely to influence policy efficacy because they help predict differences in individual compliance with the current lockdown in both countries. They do indeed. Those who choose the maximum valuation of health over wealth are twice as likely to strictly comply with lockdown guidelines in the UK and 1.5 times as likely in the US compared to everyone else (see SM, section 2d). Thus, policy makers must pay attention to the public's valuation of health over wealth not only for electoral reasons but also for reasons of policy efficacy.

We also considered whether any objective or subjective characteristics of an individual help predict their relative valuation of health over wealth (SM, section S2g). In the US, the key objective characteristic is voting for Trump, which is associated with an earlier switch point and a lower relative valuation of health over wealth. By contrast, in the UK, voting for Brexit does not help predict individual valuations, but age and education do. They are associated, respectively, with higher and lower valuation of health over wealth.

We conclude that caution in relaxing the lockdown will allow the public's currently high 
Figure 4: Health over wealth preference and lockdown compliance

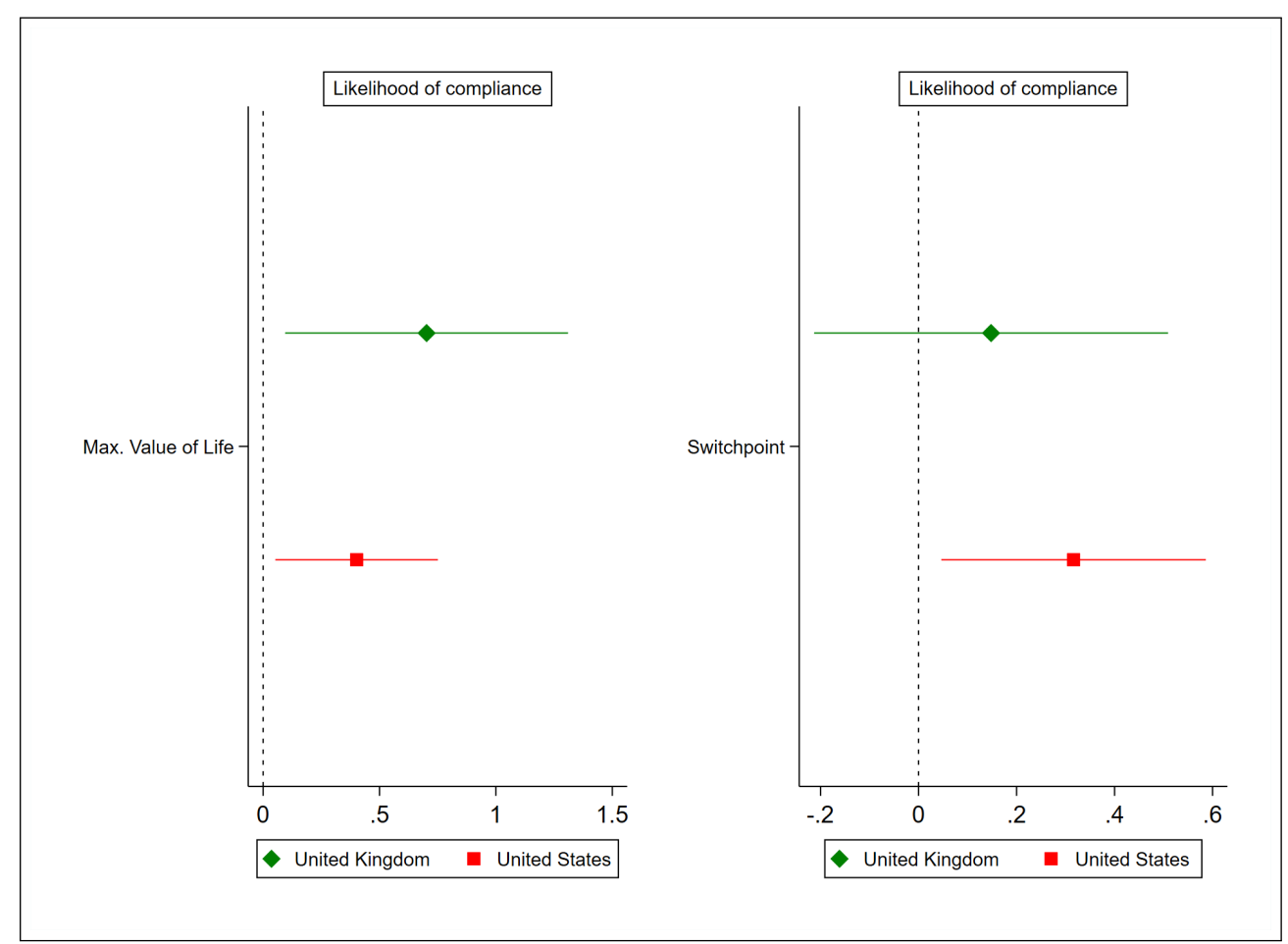

prioritization of health over wealth to evolve in ways that make compliance with a relaxation more likely. Furthermore, as there are individual differences that are also sensitive to information (see also SM, section $2 \mathrm{~h}$ ), policy makers need to be aware that the communication of policy changes could polarize these differences.

\section{References}

[1] Jonas Dehning, Johannes Zierenberg, F Paul Spitzner, Michael Wibral, Joao Pinheiro Neto, Michael Wilczek, and Viola Priesemann. Inferring covid-19 spreading rates and potential change points for case number forecasts. Science, 2020.

[2] International Monetary Fund(IMF). The great lockdown. World Economic Outlook, 2020 .

[3] Tom R Tyler. Why people obey the law. Princeton University Press, 2006.

[4] David M Kreps et al. A course in microeconomic theory. Princeton university press, 1990.

[5] Charles A Holt and Susan K Laury. Risk aversion and incentive effects. American economic review, 92(5):1644-1655, 2002. 
[6] Ian J Bateman, Richard T Carson, Brett Day, Michael Hanemann, Nick Hanley, Tannis Hett, Michael Jones-Lee, Graham Loomes, Susana Mourato, David W Pearce, et al. Economic valuation with stated preference techniques: a manual. Economic valuation with stated preference techniques: a manual, 2002.

[7] Institute for Health Metrics and Evaluation (IHME). New covid-19 forecasts for europe: Italy and spain have passed the peak of their epidemics; uk, early in its epidemic, faces a fast-mounting death toll. http://www.healthdata.org/news-release/ new-covid-19-forecasts-europe-italy-spain-have-passed-peak-their- $\backslash$ epidemics-uk-early-its, 2020. Accessed: 2020-04-16.

[8] Institute for Health Metrics and Evaluation (IHME). New ihme covid-19 forecasts show state-by-state peaks. http://www.healthdata.org/news-release/ ihme-hold-media-briefing-4-pm-eastern-today-details-below, 2020. Accessed: 2020-04-16.

[9] Egap pre-analysis registry, pap number 20200416abs. https://www.egap.org/ content/maximizing-effectiveness-policy-based-responses-covid-19-citizer.s $\%$ E2\%80\%99-preferences-over-multi.

[10] André Blais, Damien Bol, Marco Giani, and Peter John Loewen. The effect of covid-19 lockdowns on political support: Some good news for democracy? 2020.

[11] OECD. Publishing, Organisation for Economic Co-operation, and Development. Mortality risk valuation in environment, health and transport policies. OECD Publishing, 2012. 


\title{
Supplementary Material for
}

\section{COVID-19 and people's health-wealth preferences: information effects and policy implications}

\author{
Shaun Hargreaves Heap, Christel Koop, Konstantinos Matakos, Asli Unan and
} Nina Weber

\section{Contents}

1. Materials and methods
a. Data and sampling
b. Experimental design
c. Empirical strategy

2. Main empirical analysis
a. Coding of main variables of interest
b. Main treatment effects
c. "All A" - group
d. Health-wealth preferences and compliance with guidelines
e. Respecting authority in the UK
f. Estimation of implied value of life
g. Individual characteristics on health-wealth trade off
h. Additional subgroup analysis of main treatment effects

3. Robustness
a. Preference stability in control group
b. Main treatment effects with demographic controls
c. Main treatment effects with alternative coding of outcome variables
d. Main treatment effects with continuous death and loss estimates
e. Main treatment effects with alternative coding of death and loss estimates
f. Average treatment effect using post-treatment data

4. Survey instrument
a. United Kingdom
b. United States

5. References 


\section{Materials and methods}

\section{a. Data and sampling}

To conduct the online experiment, we teamed up with Prolific Academic, a web-based panel with about 35,500 participants in the United States (US) and 44,600 participants in the United Kingdom (UK) as of May 2020. Our quota-based sample was recruited between the 17th and 21st of April 2020. To generate samples for the US and the UK, we used the US Current Population Survey (1), the 2011 UK Census (2), and the Scotland's Census 2011 (3). We excluded Northern Ireland from the survey. We created a total of 170 subgroups weighted based on age, gender, region and work status. Table 1 and 2 are the stratification tables for the United Kingdom and United States, respectively, assuming a total (targeted) sample size of 2,500 respondents in each country. Table 3 reports the subgroups that we could not fill our quotas completely on Prolific and thus weighted accordingly in our analysis to ensure representativeness.

The average completion time was 33.58 minutes and respondents earned on average $£ 3.08$ for their participation. The full survey instrument that we used is available in Section 4 of this SM appendix. The data and code used for the analysis will be made available online at Harvard's Dataverse for replication purposes upon acceptance for publication.

Table 1: Stratification - United Kingdom

\begin{tabular}{|c|c|c|c|c|c|c|c|c|c|}
\hline \multirow[b]{4}{*}{ Age } & \multicolumn{9}{|c|}{ Work Status } \\
\hline & \multicolumn{5}{|c|}{$\begin{array}{c}\text { Employed (For 65+ and Scotland both Employed and } \\
\text { Unemployed) }\end{array}$} & \multicolumn{4}{|c|}{ Unemployed } \\
\hline & \multicolumn{5}{|c|}{ Regions } & \multicolumn{4}{|c|}{ Regions } \\
\hline & North & Midlands & South & Wales & Scotland & North & Midlands & South & Wales \\
\hline $16-24$ & 22.96 & 23.82 & 32.71 & 4.53 & 15.82 & 22.85 & 22.05 & 31.15 & 4.64 \\
\hline $25-34$ & 34.18 & 36.26 & 62.10 & 6.59 & 16.98 & 13.02 & 13.47 & 20.65 & 2.39 \\
\hline $35-49$ & 61.11 & 66.48 & 91.56 & 12.09 & 29.46 & 18.07 & 19.28 & 29.52 & 3.63 \\
\hline $50-64$ & 40.92 & 45.57 & 61.00 & 8.54 & 26.67 & 29.80 & 29.31 & 36.14 & 6.58 \\
\hline $65+$ & 69.89 & 75.83 & 95.66 & 15.60 & 25.39 & & & & \\
\hline $16-24$ & 23.11 & 24.62 & 32.91 & 4.70 & 15.88 & 23.63 & 22.95 & 32.27 & 4.87 \\
\hline $25-34$ & 38.23 & 41.61 & 70.96 & 7.35 & 16.47 & 8.82 & 7.89 & 11.71 & 1.74 \\
\hline $35-49$ & 64.79 & 73.30 & 103.95 & 12.66 & 27.97 & 12.74 & 11.08 & 15.29 & 2.55 \\
\hline $50-64$ & 47.57 & 54.28 & 70.33 & 9.80 & 25.62 & 22.05 & 19.19 & 23.50 & 4.82 \\
\hline $65+$ & 55.18 & 61.67 & 75.87 & 12.60 & 19.23 & & & & \\
\hline
\end{tabular}


Table 2: Stratification - United States

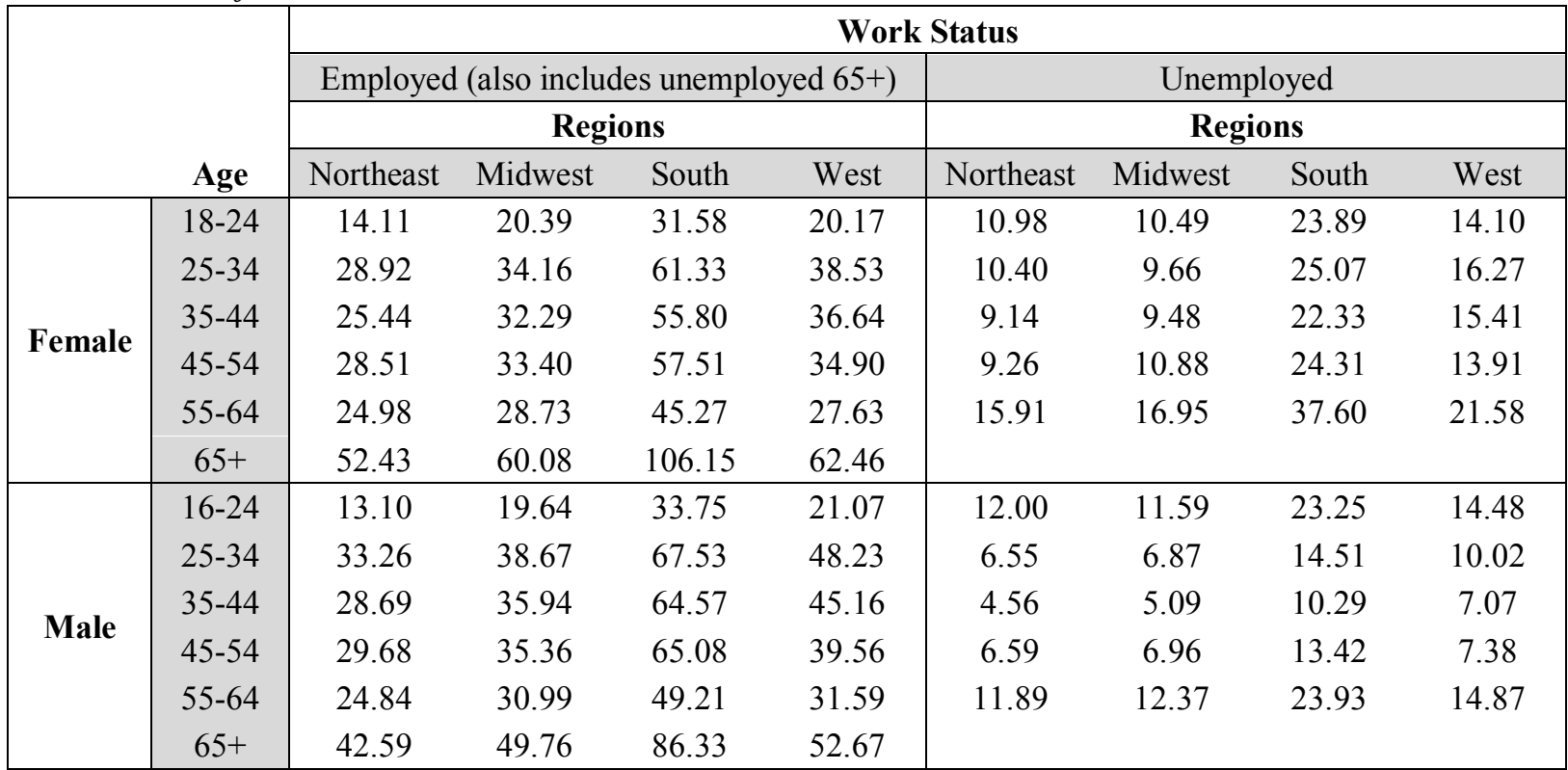

Table 3: Subgroups not filled completely

\begin{tabular}{|ccc|ccc|}
\hline \multicolumn{2}{|c|}{ United Kingdom } & \multicolumn{4}{c|}{ United States } \\
\hline Subgroup & $\begin{array}{c}\text { Sample } \\
\text { no. }\end{array}$ & $\begin{array}{c}\text { Reached } \\
\text { no. }\end{array}$ & Subgroup & $\begin{array}{c}\text { Sample } \\
\text { no. }\end{array}$ & $\begin{array}{c}\text { Reached } \\
\text { no. }\end{array}$ \\
\hline Female/North/65+ & 70 & 64 & Female/Northeast/65+ & 52 & 33 \\
\hline Male/North/65+ & 55 & 38 & $\begin{array}{c}\text { Male/Northeast/55- } \\
\text { 64/e }\end{array}$ & 25 & 12 \\
\hline Male/Midlands/65+ & 62 & 34 & Male/Northeast/65+ & 43 & 32 \\
\hline Female/South/65+ & 96 & 92 & $\begin{array}{c}\text { Male/Northeast/55- } \\
\text { 64/u }\end{array}$ & 12 & 8 \\
\hline Male/South/65+ & 76 & 43 & Female/Midwest/65+ & 60 & 28 \\
\hline Female/Wales/65+ & 16 & 8 & Male/ Midwest/65+ & 50 & 27 \\
\hline Male/Wales/65+ & 13 & 8 & Female/South/65+ & 106 & 57 \\
\hline Female/Scotland/65+ & 25 & 21 & Male/South/55-64/e & 49 & 40 \\
\hline Male/Scotland/65+ & 19 & 10 & Male/ South/65+ & 86 & 37 \\
\hline- & - & - & Male/South/55-64/u & 24 & 22 \\
\hline- & - & - & Female/West/65+ & 62 & 34 \\
\hline- & - & - & Male/West/55-64/e & 32 & 20 \\
\hline- & - & - & Male/ West/65+ & 53 & 34 \\
\hline- & - & - & Male/West/55-64/u & 15 & 12 \\
\hline
\end{tabular}

Notes: Subgroups for respondents above the age of 65 do not include a work status variable. For those below the age of 65, e indicates "employed" and u indicates "unemployed".

\section{b. Experimental design}

Our survey experiment consisted of a sequence of eight binary choices between pairs of health and wealth outcomes. Respondents read a short text on how restrictions on personal movements help contain the spread of coronavirus and save lives but with a cost of disrupting and lowering economic activity. They were then presented with eight decisions with each option giving a 
combination of 'lives lost per 1 million of the population through Covid-19 over the next 3 months' and 'the average loss of household income due to measures to prevent transmission of Covid-19 over the next 3 months. In each of the eight decisions, they clicked on the option that they think has the best combination.

We asked respondents to make these decisions a second time after engaging in an unrelated task. Prior to repeating the task, respondents were divided into three groups. One treatment had information about COVID-19 deaths; the other had information on income losses due to COVID-19 lockdown. A control group heard a short piece of music instead of information. Prior to treatment, they were further asked to provide their estimates of the (expected) number of lives and amount of income lost due to COVID-19 and the associated lockdown.

Treatment information: Our treatment consists of two types of information prompts that are shown to the survey respondents. The first prompt provides information about estimated lives that will be lost (in the US and the UK) by August 2020 according to the IMHE (4). The second prompt provides respondents with information on expected income (GDP) loses based on estimates presented by the IMF (2). We present the exact wording of the two information treatments in Section 4 of this SM appendix.

\section{c. Empirical strategy}

To estimate our main treatment effects, we analysed the data using two statistical forms - an ordinary least squares (OLS) regression and a logistic regression - in order to identify the causal effects of our treatment and how they interacted with respondent $i$ 's estimate of deaths and income lost. Treatment assignment to one of the two groups (plus the control group) was fully randomized. Such analysis allows us to understand which of the variables has a significant impact on health-wealth prioritization.

We estimated the following two basic empirical models, whereby $H L_{i}$ is the change (between the two rounds) in respondent $i$ 's preference over health and wealth, $\delta_{1}$ is the treatment effect, $\delta_{2}$ the effect of respondent $i$ 's estimate of deaths interacted with the health treatment (T1), $\delta_{3}$ the effect of respondent $i$ 's estimate of the income loss interacted with the wealth treatment (T2) and $\varepsilon_{i}$ the error term. In all our main specifications we used population weights (as specified in Section 1a above) in order to able to make inference for the general US and UK populations. We also clustered our standard errors at the regional level (US States and UK NUTS-2 areas). Formally, we estimate the following equations:

$$
\begin{aligned}
& H L_{i}=\beta_{0}+\delta_{1} \text { treatment }+\varepsilon_{i} \\
& H L_{i}=\beta_{0}+\delta_{1} \text { treatment }+\delta_{2} t 1 \text { xeathest }_{i}+\delta_{3} \text { t } 2{\text { x } \text { incomeest }_{i}+\varepsilon_{i}}
\end{aligned}
$$

Given that we are interested in within subject changes between pre- and post-treatment preferences we do not control for demographics in our main estimation. Section $3 \mathrm{~b}$ includes the main treatment effects with demographic controls. Parameters $\delta_{1}, \delta_{2}$, and $\delta_{3}$ capture the causal estimates of our treatment effects. Random assigned to treatment ensures the causal interpretation of OLS estimates. The results of our main analysis are reported in tables 4-7 below. 
Outcomes: Our outcome variable $H L$ is measured in five different ways. We have two categories of outcomes: a) binary ones (Switching Up; Switching Down; Down from maximum value of life (VoL); Up to maximum $\mathrm{VoL}$ ) and b) a continuous one (VoL). We detail each one of them (and how we computed them) in S2a. In order to collect the outcome information, we simply analyzed the responses that subjects gave in the two parts of the survey that contained the eight binary decisions. The exact phrasing of those binary decisions and the questions used to collect the outcome data can be found in Section 4 of this SM appendix where we have included the full survey instrument.

\section{Main empirical analysis}

\section{a. Coding of main variables of interest}

Switch point

Categorical variable between 1 and 8 depending on the decision at which respondent $i$ switched from option A to B.

Switching Up

Binary variable equal to 1 if respondent $i$ 's switch point is earlier post-treatment than pretreatment.

\section{Switching Down}

Binary variable equal to 1 if respondent $i$ 's switch point is later post-treatment than pretreatment.

\section{Top Value of Life (or maximum Value of Life)}

Binary variable equal to 1 if respondent $i$ switched from A to B at decision 8 .

\section{Down from max. VoL}

Binary variable equal to 1 if respondent $i$ switched from A to B at decision 8 pre-treatment but switched at an earlier decision post-treatment.

Up to max. VoL

Binary variable equal to 1 if respondent $i$ switched from A to B at decision 8 post-treatment but switches at an earlier decision pre-treatment.

\section{Value of Life (VoL)}

Continuous variable capturing respondent $i$ 's minimum value of life elicited by the implied value of life of respondent $i$ 's switch point. Section $2 \mathrm{f}$ lists the implied value of life for each switch point in the UK and US, respectively.

\section{Death estimates}

Categorical variable equal to 0 if respondent $i$ 's estimate of deaths due to covid-19 is within a range of $+/-5,000$ relative to the IMHE estimate at the time of surveying, equal to 1 if above and equal to -1 if below the range. 


\section{Income estimates}

Categorical variable equal to 0 if respondent $i$ 's estimate of the income loss due to covid-19 is within a range of $+/-1 \%$ relative to the IMF estimate at the time of surveying, equal to 1 if above and equal to -1 if below the range.

\section{b. Main treatment effects}

Table 4: Main treatment effects without interactions (Top Value of Life)

\begin{tabular}{|c|c|c|c|c|}
\hline & \multicolumn{4}{|c|}{ Main treatment effects } \\
\hline & $\begin{array}{c}\text { Down from } \\
\text { max. VoL } \\
(\mathrm{UK}) \\
\end{array}$ & $\begin{array}{c}\text { Up to } \\
\text { max. VoL } \\
(\mathrm{UK}) \\
\end{array}$ & $\begin{array}{c}\text { Down from } \\
\text { max. VoL } \\
\text { (US) } \\
\end{array}$ & $\begin{array}{l}\text { Up to max. } \\
\text { VoL (US) } \\
\end{array}$ \\
\hline \multicolumn{5}{|l|}{ Treatment } \\
\hline Health treatment (T1) & $\begin{array}{c}0.383 \\
(0.367)\end{array}$ & $\begin{array}{l}-0.987 \\
(0.600)\end{array}$ & $\begin{array}{c}0.141 \\
(0.431)\end{array}$ & $\begin{array}{c}0.434 \\
(0.466)\end{array}$ \\
\hline Wealth treatment (T2) & $\begin{array}{l}0.514^{*} \\
(0.306)\end{array}$ & $\begin{array}{l}-0.121 \\
(0.477)\end{array}$ & $\begin{array}{l}-0.506 \\
(0.556)\end{array}$ & $\begin{array}{c}0.309 \\
(0.533)\end{array}$ \\
\hline Constant & $\begin{array}{c}-3.711 * * * \\
(0.221)\end{array}$ & $\begin{array}{c}-3.608 * * * \\
(0.310)\end{array}$ & $\begin{array}{c}-3.516^{* * *} \\
(0.343)\end{array}$ & $\begin{array}{c}-4.001 * * * \\
(0.345)\end{array}$ \\
\hline Regional clustering & $\checkmark$ & $\checkmark$ & $\checkmark$ & $\checkmark$ \\
\hline Observations & 1,661 & 1,661 & 1,382 & 1,382 \\
\hline Pseudo R-squared & 0.005 & 0.015 & 0.007 & 0.003 \\
\hline
\end{tabular}

Notes: Estimates come from a logistic regression. Regional clustering is done based on either the 12 regions of the UK, as defined by the ONS or the 50 states of the United States, as defined by the Census Bureau. Clustered standard errors are presented in parentheses. ${ }^{* * *} \mathrm{p}<0.01,{ }^{*} \mathrm{p}<0.05,{ }^{*} \mathrm{p}<0.1$.

Table 5: Main treatment effects without interactions (Switch point)

\begin{tabular}{lcccc} 
& \multicolumn{5}{c}{ Main treatment effects } \\
& $\begin{array}{c}\text { Switch up } \\
\text { (UK) }\end{array}$ & $\begin{array}{c}\text { Switch } \\
\text { down (UK) }\end{array}$ & $\begin{array}{c}\text { Switch up } \\
\text { (US) }\end{array}$ & $\begin{array}{c}\text { Switch } \\
\text { down (US) }\end{array}$ \\
\hline \hline Treatment & & & & \\
\hline & -0.209 & -0.061 & $0.235^{*}$ & 0.099 \\
Health treatment (T1) & $(0.192)$ & $(0.129)$ & $(0.137)$ & $(0.163)$ \\
\hline & -0.131 & 0.136 & 0.045 & 0.135 \\
Wealth treatment (T2) & $(0.112)$ & $(0.177)$ & $(0.142)$ & $(0.154)$ \\
\hline & $-1.169 * * *$ & $-1.478^{* * *}$ & $-2.039^{* * *}$ & $-2.068^{* * *}$ \\
Constant & $(0.107)$ & $(0.112)$ & $(0.087)$ & $(0.093)$ \\
\hline \hline Regional clustering & $\checkmark$ & $\checkmark$ & $\checkmark$ & $\checkmark$ \\
\hline Observations & 2,399 & 2,399 & 2,245 & 2,245 \\
\hline Pseudo R-squared & 0.001 & 0.001 & 0.002 & 0.001 \\
\hline \hline
\end{tabular}


Notes: Estimates come from a logistic regression. Regional clustering is done based on either the 12 regions of the UK, as defined by the ONS or the 50 states of the United States, as defined by the Census Bureau. Clustered standard errors are presented in parentheses. ${ }^{* * *} \mathrm{p}<0.01,{ }^{* *} \mathrm{p}<0.05,{ }^{*} \mathrm{p}<0.1$.

Table 6: Main treatment effects with interactions (Top Value of Life)

\begin{tabular}{|c|c|c|c|c|}
\hline & \multicolumn{4}{|c|}{ Main treatment effects } \\
\hline & $\begin{array}{c}\text { Down from } \\
\text { max. VoL } \\
(\mathrm{UK}) \\
\end{array}$ & $\begin{array}{c}\text { Up to } \\
\text { max. VoL } \\
(\mathrm{UK}) \\
\end{array}$ & $\begin{array}{c}\text { Down from } \\
\text { max. VoL } \\
\text { (US) }\end{array}$ & $\begin{array}{l}\text { Up to max. } \\
\text { VoL (US) } \\
\end{array}$ \\
\hline \multicolumn{5}{|l|}{ Treatment } \\
\hline Health treatment (T1) & $\begin{array}{l}0.748^{*} \\
(0.453)\end{array}$ & $\begin{array}{l}-0.453 \\
(1.226)\end{array}$ & $\begin{array}{c}0.215 \\
(0.493)\end{array}$ & $\begin{array}{c}0.467 \\
(0.501)\end{array}$ \\
\hline Wealth treatment (T2) & $\begin{array}{l}-0.036 \\
(0.346)\end{array}$ & $\begin{array}{l}-0.195 \\
(0.575)\end{array}$ & $\begin{array}{l}-1.341^{*} \\
(0.690)\end{array}$ & $\begin{array}{c}0.332 \\
(0.545)\end{array}$ \\
\hline \multicolumn{5}{|l|}{ Income Estimate } \\
\hline T2 $x$ Underestimate & $\begin{array}{c}1.108 * * * \\
(0.228)\end{array}$ & $\begin{array}{c}0.214 \\
(0.581)\end{array}$ & $\begin{array}{c}1.886^{* * * *} \\
(0.675)\end{array}$ & $\begin{array}{l}-0.074 \\
(0.751)\end{array}$ \\
\hline T2 $x$ Overestimate & omitted & omitted & omitted & omitted \\
\hline \multicolumn{5}{|l|}{ Death Estimate } \\
\hline T1 $x$ Underestimate & $\begin{array}{l}-0.613 \\
(0.665)\end{array}$ & $\begin{array}{c}-1.739 * * * \\
(0.119)\end{array}$ & $\begin{array}{l}-0.165 \\
(0.536)\end{array}$ & $\begin{array}{l}-0.070 \\
(0.583)\end{array}$ \\
\hline T1 $x$ Overestimate & $\begin{array}{l}-0.190 \\
(0.413)\end{array}$ & $\begin{array}{c}0.054 \\
(1.197)\end{array}$ & omitted & omitted \\
\hline Constant & $\begin{array}{c}-3.711^{* * *} \\
(0.221)\end{array}$ & $\begin{array}{c}-3.608 * * * \\
(0.310)\end{array}$ & $\begin{array}{c}-3.516 * * * \\
(0.343)\end{array}$ & $\begin{array}{c}-4.001 * * * \\
(0.345)\end{array}$ \\
\hline Regional clustering & $\checkmark$ & $\checkmark$ & $\checkmark$ & $\checkmark$ \\
\hline Observations & 1,654 & 1,654 & 1,379 & 1,379 \\
\hline Pseudo R-squared & 0.020 & 0.027 & 0.027 & 0.003 \\
\hline
\end{tabular}

Notes: Estimates come from a logistic regression. Regional clustering is done based on either the 12 regions of the UK, as defined by the ONS or the 50 states of the United States, as defined by the Census Bureau. Clustered standard errors are presented in parentheses. ${ }^{* * *} \mathrm{p}<0.01,{ }^{* *} \mathrm{p}<0.05,{ }^{*} \mathrm{p}<0.1$. 
Main treatment effects

\begin{tabular}{|c|c|c|c|c|}
\hline & $\begin{array}{l}\text { Switch up } \\
\text { (UK) }\end{array}$ & $\begin{array}{c}\text { Switch } \\
\text { down (UK) }\end{array}$ & $\begin{array}{l}\text { Switch up } \\
\text { (US) }\end{array}$ & $\begin{array}{c}\text { Switch } \\
\text { down (US) }\end{array}$ \\
\hline \multicolumn{5}{|l|}{ Treatment } \\
\hline Health treatment & $\begin{array}{l}-0.129 \\
(0.379)\end{array}$ & $\begin{array}{l}-0.853 \\
(0.584)\end{array}$ & $\begin{array}{c}0.095 \\
(0.155)\end{array}$ & $\begin{array}{c}0.196 \\
(0.213)\end{array}$ \\
\hline Wealth treatment & $\begin{array}{l}1.071 * \\
(0.637)\end{array}$ & $\begin{array}{l}-0.256 \\
(0.908)\end{array}$ & $\begin{array}{l}-0.712 \\
(1.092)\end{array}$ & $\begin{array}{c}0.095 \\
(0.177)\end{array}$ \\
\hline \multicolumn{5}{|l|}{ Income Estimate } \\
\hline T2 $x$ Underestimate & $\begin{array}{l}-1.087 \\
(0.715)\end{array}$ & $\begin{array}{c}0.313 \\
(0.910)\end{array}$ & $\begin{array}{c}0.726 \\
(1.086)\end{array}$ & $\begin{array}{c}0.218 \\
(0.243)\end{array}$ \\
\hline T2 $x$ Overestimate & $\begin{array}{c}-1.336^{* *} \\
(0.620)\end{array}$ & $\begin{array}{c}0.451 \\
(0.920)\end{array}$ & $\begin{array}{c}0.782 \\
(1.105)\end{array}$ & omitted \\
\hline \multicolumn{5}{|l|}{ Death Estimate } \\
\hline T1 $x$ Underestimate & $\begin{array}{l}-0.198 \\
(0.321)\end{array}$ & $\begin{array}{c}0.686 \\
(0.591)\end{array}$ & $\begin{array}{l}0.318^{*} \\
(0.190)\end{array}$ & $\begin{array}{l}-0.225 \\
(0.246)\end{array}$ \\
\hline T1 x Overestimate & $\begin{array}{c}0.083 \\
(0.318)\end{array}$ & $\begin{array}{c}1.039 \\
(0.632)\end{array}$ & omitted & omitted \\
\hline Constant & $\begin{array}{c}-1.175^{* * *} \\
(0.105)\end{array}$ & $\begin{array}{c}-2.033 * * * \\
(0.088) \\
\end{array}$ & $\begin{array}{c}-1.494 * * * \\
(0.112)\end{array}$ & $\begin{array}{c}-2.060 * * * \\
(0.094)\end{array}$ \\
\hline Regional clustering & $\checkmark$ & $\checkmark$ & $\checkmark$ & $\checkmark$ \\
\hline Observations & 2,380 & 2,380 & 2,229 & 2,220 \\
\hline Pseudo R-squared & 0.004 & 0.005 & 0.004 & 0.002 \\
\hline
\end{tabular}

Notes: Estimates come from a logistic regression. Regional clustering is done based on either the 12 regions of the UK, as defined by the ONS or the 50 states of the United States, as defined by the Census Bureau. Clustered standard errors are presented in parentheses. $* * * \mathrm{p}<0.01, * * \mathrm{p}<0.05, * \mathrm{p}<0.1$.

\section{c. "All A" - group}

A significant proportion of respondents (12\% pre-treatment and $9 \%$ post-treatment) chose option A for all eight decisions. Given that these respondents chose a weakly dominated option (the same number of deaths for a higher income loss), we do not include these subjects into our main treatment effects analysis. Instead, we analyzed separately how our treatments affected respondents' move to and from choosing option A for all decisions. Table 8 reports the treatment effects on this particular group of respondents. 


\section{Main treatment effects}

Down from Up to "all Down from Up to "all

"all A" (UK) A" (UK) “all A" (US) A" (US)

\begin{tabular}{lcccc}
\hline Treatment & & & & \\
\hline & $-0.587 * *$ & $0.767 * *$ & 0.397 & 0.181 \\
Health treatment (T1) & $(0.241)$ & $(0.332)$ & $(0.256)$ & $(0.47)$ \\
\hline & -0.260 & 0.505 & 0.022 & -0.144 \\
Wealth treatment (T2) & $(0.265)$ & $(0.363)$ & $(0.319)$ & $(0.439)$ \\
\hline & $-2.760^{* * *}$ & $-4.506^{* * *}$ & $-2.768^{* * *}$ & $-3.695^{* * *}$ \\
Constant & $(0.130)$ & $(0.329)$ & $(0.201)$ & $(0.264)$ \\
\hline \hline Regional clustering & $\checkmark$ & $\checkmark$ & $\checkmark$ & $\checkmark$ \\
\hline Observations & 1,884 & 1,884 & 1,665 & 1,665 \\
\hline Pseudo R-squared & 0.007 & 0.009 & 0.005 & 0.002 \\
\hline \hline
\end{tabular}

Notes: Estimates come from a logistic regression. Regional clustering is done based on either the 12 regions of the UK, as defined by the ONS or the 50 states of the United States, as defined by the Census Bureau. Clustered standard errors are presented in parentheses. ${ }^{* * *} \mathrm{p}<0.01, * * \mathrm{p}<0.05, * \mathrm{p}<0.1$.

\section{d. Health-wealth preferences and compliance with guidelines}

To assess the likelihood of compliance with government guidelines, we use pre-treatment question 3 ("How likely are you to follow the government's guidance for reducing the spread of Covid-19?") and regress our outcome variables on the answer respondents gave to this question. Specifically, we formally estimate the below model, whereby $\mathrm{Compl}_{\mathrm{i}}$ is measured as 1) a categorical variable, ranging from 1 to 5 , equal to the value respondents selected on pretreatment question 3 with a higher value indicating a higher likelihood of compliance and 2) as a binary variable equal to 1 if respondents selected the answer "Very likely" and equal to 0 otherwise. As we are estimating the pre-treatment relationship, we include a vector of controls $\gamma_{i}$.

$$
\operatorname{Compl}_{i}=\beta_{0}+\delta_{1} H L_{i}+\gamma_{i}+\varepsilon_{i}
$$

Table 9 reports the results using the categorical outcome variable and table 10 reports the results of the binary outcome variable. Both, choosing the maximum value of life and the switch point, excluding the maximum value of life, affect compliance with government guidelines in the US; yet, only the maximum value of life affects compliance in the UK. This finding further emphasizes the importance of our main treatment effects, as these are all related to the maximum value of life and not to the switch point people have more broadly. 


\section{Pre-treatment compliance (categorical)}

\begin{tabular}{cccc} 
Max. Value & $\begin{array}{c}\text { Switch } \\
\text { of Life (UK) }\end{array}$ & $\begin{array}{l}\text { Max. Value } \\
\text { point (UK) }\end{array}$ & $\begin{array}{c}\text { Switch } \\
\text { point (US) }\end{array}$ \\
\hline
\end{tabular}

\begin{tabular}{|c|c|c|c|c|}
\hline Max Value of Life & $\begin{array}{c}0.702 * * \\
(0.310)\end{array}$ & - & $\begin{array}{c}0.402 * * \\
(0.178)\end{array}$ & - \\
\hline Switch point & - & $\begin{array}{c}0.148 \\
(0.184)\end{array}$ & - & $\begin{array}{c}0.316^{* *} \\
(0.138)\end{array}$ \\
\hline Demographic controls & $\checkmark$ & $\checkmark$ & $\checkmark$ & $\checkmark$ \\
\hline Regional clustering & $\checkmark$ & $\checkmark$ & $\checkmark$ & $\checkmark$ \\
\hline Observations & 1,131 & 506 & 1,142 & 409 \\
\hline Pseudo R-squared & 0.178 & 0.253 & 0.118 & 0.188 \\
\hline
\end{tabular}

Notes: Estimates come from an ordered logistic regression. The Switch point regressions exclude those respondents with a switch point equal to 8 to capture the difference across switch points as opposed to the effect of choosing the maximum value of life. Regional clustering is done based on either the 12 regions of the UK, as defined by the ONS or the 50 states of the United States, as defined by the Census Bureau. Clustered standard errors are presented in parentheses. ${ }^{* * *} \mathrm{p}<0.01,{ }^{* *} \mathrm{p}<0.05,{ }^{*} \mathrm{p}<0.1$.

Table 10: Compliance with guidelines

\begin{tabular}{lcccc}
\hline & \multicolumn{5}{c}{ Pre-treatment compliance (binary) } \\
& $\begin{array}{c}\text { Max. Value } \\
\text { of Life (UK) }\end{array}$ & $\begin{array}{c}\text { Switch } \\
\text { point (UK) }\end{array}$ & $\begin{array}{c}\text { Max. Value } \\
\text { of Life (US) }\end{array}$ & $\begin{array}{c}\text { Switch } \\
\text { point (US) }\end{array}$ \\
\hline \hline & & & & \\
\hline & $0.761^{* * *}$ & & $0.378^{* *}$ & - \\
\hline Max Value of Life & $(0.280)$ & & $(0.181)$ & $-289^{* *}$ \\
Switch point & - & 0.163 & - & $(0.115)$ \\
\hline \hline Demographic controls & $\checkmark$ & $(0.179)$ & $\checkmark$ & $\checkmark$ \\
\hline Regional clustering & $\checkmark$ & $\checkmark$ & $\checkmark$ & $\checkmark$ \\
\hline Observations & 1,026 & 426 & 1,120 & 400 \\
\hline Pseudo R-squared & 0.197 & 0.266 & 0.139 & 0.226 \\
\hline \hline
\end{tabular}

Notes: Estimates come from a logistic regression. The Switch point regressions exclude those respondents with a switch point equal to 8 to capture the difference across switch points as opposed to the effect of choosing the maximum value of life. Regional clustering is done based on either the 12 regions of the UK, as defined by the ONS or the 50 states of the United States, as defined by the Census Bureau. Clustered standard errors are presented in parentheses. $* * * \mathrm{p}<0.01, * * \mathrm{p}<0.05, * \mathrm{p}<0.1$.

\section{e. Respecting authority in the UK}

As can be seen in table 6, UK respondents who underestimated the number of deaths and were assigned the Covid-19 deaths treatment were less likely to move to the top value of life posttreatment. This surprising result can be explained by people's respect for authority as table 11 
reports below. The higher people scored on demographic question D9 (a higher score indicating a preference to question authority), the more likely people who underestimated deaths and were assigned the deaths information treatment were to reduce their likelihood of choosing the maximum value of life. We interpret this result as an information backlash. People who question authority are sceptical of the information we provide them with and subsequently do not update their preferences on the health-wealth trade-off in response to our information. Table 11 also indicates that including this interaction switches the signs of the interaction between death treatment and underestimate of deaths without authority into the 'correct' direction, further supporting the explanatory power of including respect for authority into the analysis.

Table 11: Authority interaction in the UK

Interactions with respect for Authority

Down from

max. VoL Up to max. Switch up Switch

$\begin{array}{llll}(\mathrm{UK}) & \text { VoL }(\mathrm{UK}) & (\mathrm{UK}) & \operatorname{down}(\mathrm{UK})\end{array}$

\begin{tabular}{|c|c|c|c|c|}
\hline \multicolumn{5}{|l|}{ Treatment } \\
\hline Health treatment & $\begin{array}{c}0.588 \\
(1.646)\end{array}$ & $\begin{array}{c}-4.694 * * * \\
(1.473)\end{array}$ & $\begin{array}{c}0.073 \\
(0.721)\end{array}$ & $\begin{array}{c}-2.245 * * * \\
(0.452)\end{array}$ \\
\hline Wealth treatment & $\begin{array}{l}-0.022 \\
(0.349)\end{array}$ & $\begin{array}{l}-0.177 \\
(0.577)\end{array}$ & $\begin{array}{c}1.047 \\
(0.636)\end{array}$ & $\begin{array}{l}-0.262 \\
(0.910)\end{array}$ \\
\hline \multicolumn{5}{|l|}{ Income Estimate } \\
\hline T2 $x$ Underestimate & $\begin{array}{c}1.074 * * * \\
(0.232)\end{array}$ & $\begin{array}{c}0.202 \\
(0.585)\end{array}$ & $\begin{array}{l}-1.132 \\
(0.711)\end{array}$ & $\begin{array}{c}0.328 \\
(0.923)\end{array}$ \\
\hline T2 $x$ Overestimate & omitted & omitted & $\begin{array}{c}-1.302 * * \\
(0.614)\end{array}$ & $\begin{array}{c}0.468 \\
(0.928)\end{array}$ \\
\hline \multicolumn{5}{|l|}{ Death Estimate } \\
\hline T1 $x$ Underestimate & $\begin{array}{l}-0.179 \\
(1.687)\end{array}$ & $\begin{array}{c}6.351 * * * \\
(0.896)\end{array}$ & $\begin{array}{l}-0.535 \\
(0.959)\end{array}$ & $\begin{array}{c}2.092 * * * \\
(0.721)\end{array}$ \\
\hline T1 $x$ Overestimate & $\begin{array}{l}-0.883 \\
(2.238)\end{array}$ & $\begin{array}{c}5.569 * * * \\
(1.578)\end{array}$ & $\begin{array}{c}0.472 \\
(0.863)\end{array}$ & $\begin{array}{c}2.541 * * * \\
(0.707)\end{array}$ \\
\hline Questioning Authority & $\begin{array}{l}-0.039 \\
(0.042)\end{array}$ & $\begin{array}{c}0.044 \\
(0.055)\end{array}$ & $\begin{array}{c}-0.039 * * \\
(0.019)\end{array}$ & $\begin{array}{l}-0.029 \\
(0.032)\end{array}$ \\
\hline T1 $x$ Underest. $x$ Authority & $\begin{array}{l}-0.062 \\
(0.081)\end{array}$ & $\begin{array}{c}-1.639 * * * \\
(0.304)\end{array}$ & $\begin{array}{c}0.019 \\
(0.065)\end{array}$ & $\begin{array}{c}0.000 \\
(0.066)\end{array}$ \\
\hline T1 $x$ Overest. $x$ Authority & $\begin{array}{c}0.162 \\
(0.170)\end{array}$ & $\begin{array}{l}-0.280 \\
(0.243)\end{array}$ & $\begin{array}{c}-0.124 * * \\
(0.056)\end{array}$ & $\begin{array}{l}-0.028 \\
(0.064)\end{array}$ \\
\hline $\begin{array}{l}\text { T1 } x \text { Correct est. } x \\
\text { Authority }\end{array}$ & $\begin{array}{c}0.031 \\
(0.326)\end{array}$ & $\begin{array}{c}0.630^{* * *} \\
(0.165)\end{array}$ & $\begin{array}{l}-0.041 \\
(0.158)\end{array}$ & $\begin{array}{c}0.254 * * * \\
(0.084)\end{array}$ \\
\hline Constant & $\begin{array}{c}-3.515^{* * * *} \\
(0.320)\end{array}$ & $\begin{array}{c}-3.813 * * * \\
(0.425)\end{array}$ & $\begin{array}{c}-0.970 * * * \\
(0.127)\end{array}$ & $\begin{array}{c}-1.896^{* * *} \\
(0.173)\end{array}$ \\
\hline Regional clustering & $\checkmark$ & $\checkmark$ & $\checkmark$ & $\checkmark$ \\
\hline Observations & 1,628 & 1,628 & 2,321 & 2,321 \\
\hline Pseudo R-squared & 0.023 & 0.049 & 0.010 & 0.006 \\
\hline
\end{tabular}


Notes: Estimates come from a logistic regression. Regional clustering is done based on either the 12 regions of the UK, as defined by the ONS or the 50 states of the United States, as defined by the Census Bureau. Clustered standard errors are presented in parentheses. *** $\mathrm{p}<0.01, * * \mathrm{p}<0.05,{ }^{*} \mathrm{p}<0.1$.

\section{f. Estimation of implied value of life}

Further to our main analysis of individuals' switch points we estimated their implied minimum value of life. Table 12 lists the implied value of life for the UK and the US given the decision at which subject i switched from A to B.

Table 12: Implied value of life

Minimum Value of Life given switch from A to B

United Kingdom

United States

\begin{tabular}{lcc}
\hline \hline & - & - \\
\hline Decision 1 & $£ 1.73 \mathrm{~m}$ & $\$ 2.9 \mathrm{~m}$ \\
\hline Decision 2 & $£ 4.1 \mathrm{~m}$ & $\$ 7.4 \mathrm{~m}$ \\
\hline Decision 3 & $£ 7.8 \mathrm{~m}$ & $\$ 13 \mathrm{~m}$ \\
\hline Decision 4 & $£ 12.3 \mathrm{~m}$ & $\$ 19.5 \mathrm{~m}$ \\
\hline Decision 5 & $£ 20.5 \mathrm{~m}$ & $\$ 29.2 \mathrm{~m}$ \\
\hline Decision 6 & $£ 32.8 \mathrm{~m}$ & $\$ 45.5 \mathrm{~m}$ \\
\hline Decision 7 & - & - \\
\hline Decision 8 & & \\
\hline \hline
\end{tabular}

\section{g. Individual characteristics on health-wealth trade-off}

To assess the impact of demographic variables on individuals' perceptions of the health-wealth trade-off, we regressed our set of demographic variables on the estimated minimum value of life implied by people's choices in the preference elicitation task. Table 13 reports the results for the United Kingdom and table 14 the results for the United States.

Table 13: Value of life pre-treatment demographics UK in $£ 100,000$

Without death estimates Including death estimates

\begin{tabular}{ccc}
\hline \hline & & \\
\hline \multirow{2}{*}{ Estimates of Covid-19 deaths } & - & -0.00 \\
& & $(0.00)$ \\
\hline \multirow{2}{*}{ Female } & -5.64 & -10.40 \\
& $(7.42)$ & $(7.67)$ \\
\hline \multirow{2}{*}{ Age (categories) } & $11.62^{* * *}$ & $15.64 * * *$ \\
Regions & $(3.40)$ & $(4.36)$ \\
\hline
\end{tabular}




\begin{tabular}{|c|c|c|}
\hline Wales & $\begin{array}{l}-12.85 \\
(10.56)\end{array}$ & $\begin{array}{l}-16.64 \\
(10.47)\end{array}$ \\
\hline Scotland & $\begin{array}{l}-3.05 \\
(8.25)\end{array}$ & $\begin{array}{c}0.09 \\
(7.48)\end{array}$ \\
\hline \multicolumn{3}{|l|}{ Ethnicity } \\
\hline Any other white background & $\begin{array}{l}17.91 * \\
(8.47)\end{array}$ & $\begin{array}{c}22.21 * * \\
(8.07)\end{array}$ \\
\hline White and Black Caribbean & $\begin{array}{c}-211.80 * * * \\
(30.55)\end{array}$ & $\begin{array}{c}-231.67 * * * \\
(30.67)\end{array}$ \\
\hline White and Black African & $\begin{array}{c}22.85 \\
(37.81)\end{array}$ & $\begin{array}{l}-10.69 \\
(94.75)\end{array}$ \\
\hline White and Asian & $\begin{array}{c}35.23 \\
(45.63)\end{array}$ & $\begin{array}{c}49.39 \\
(42.25)\end{array}$ \\
\hline Any other mixed background & $\begin{array}{l}-34.24 \\
(43.68)\end{array}$ & $\begin{array}{l}-19.24 \\
(54.07)\end{array}$ \\
\hline Indian & $\begin{array}{c}27.28 \\
(58.21)\end{array}$ & $\begin{array}{l}-10.08 \\
(61.71)\end{array}$ \\
\hline Pakistani & $\begin{array}{l}-62.98 \\
(97.61)\end{array}$ & $\begin{array}{c}-62.09 \\
(124.86)\end{array}$ \\
\hline Bangladeshi & $\begin{array}{c}40.48 \\
(59.14)\end{array}$ & $\begin{array}{c}38.54 \\
(103.82)\end{array}$ \\
\hline Chinese & $\begin{array}{l}-11.32 \\
(85.45)\end{array}$ & $\begin{array}{c}-4.49 \\
(86.50)\end{array}$ \\
\hline Any other Asian background & $\begin{array}{l}-47.08 \\
(37.97)\end{array}$ & $\begin{array}{l}032.54 \\
(86.19)\end{array}$ \\
\hline Black Caribbean & $\begin{array}{c}40.80 \\
(54.22)\end{array}$ & $\begin{array}{c}14.22 \\
(53.17)\end{array}$ \\
\hline Black African & $\begin{array}{c}89.53 * * \\
(39.78)\end{array}$ & $\begin{array}{l}95.30 * \\
(43.95)\end{array}$ \\
\hline Other ethnic group & $\begin{array}{l}-78.49 \\
(78.63)\end{array}$ & $\begin{array}{c}-169.44 * * * \\
(29.53)\end{array}$ \\
\hline Prefer not to answer & $\begin{array}{c}98.26^{* *} \\
(31.16)\end{array}$ & $\begin{array}{c}106.93 * * \\
(45.48)\end{array}$ \\
\hline Income & $\begin{array}{l}-0.93 \\
(1.35)\end{array}$ & $\begin{array}{l}-2.25 \\
(2.31)\end{array}$ \\
\hline \multicolumn{3}{|l|}{ Political Party } \\
\hline Labour & $\begin{array}{c}9.27 \\
(16.28)\end{array}$ & $\begin{array}{c}2.26 \\
(14.80)\end{array}$ \\
\hline Liberal Democrat & $\begin{array}{c}5.10 \\
(15.76)\end{array}$ & $\begin{array}{c}-5.50 \\
(15.36)\end{array}$ \\
\hline Scottish National Party (SNP) & $\begin{array}{l}29.61^{*} \\
(15.81)\end{array}$ & $\begin{array}{l}35.30 * * \\
(13.57)\end{array}$ \\
\hline Plaid Cymru & $\begin{array}{l}-39.36 \\
(44.03)\end{array}$ & $\begin{array}{l}-28.05 \\
(38.30)\end{array}$ \\
\hline The Brexit Party & $\begin{array}{c}-6.60 \\
(26.09)\end{array}$ & $\begin{array}{l}-20.27 \\
(32.44)\end{array}$ \\
\hline Green Party & $\begin{array}{c}1.41 \\
(13.49)\end{array}$ & $\begin{array}{c}0.53 \\
(15.52)\end{array}$ \\
\hline$U K I P$ & $\begin{array}{c}-4.09 \\
(29.62)\end{array}$ & $\begin{array}{l}-11.89 \\
(39.87)\end{array}$ \\
\hline Sinn Fein & $\begin{array}{c}88.56 * * \\
(37.68)\end{array}$ & - \\
\hline$S D L P$ & $\begin{array}{l}-29.63 \\
(33.26)\end{array}$ & $\begin{array}{l}-87.75 \\
(75.85)\end{array}$ \\
\hline \multicolumn{3}{|l|}{ Brexit Vote } \\
\hline Leave & $\begin{array}{c}22.79 \\
(16.88)\end{array}$ & $\begin{array}{c}23.67 \\
(20.89)\end{array}$ \\
\hline Remain & $\begin{array}{c}10.66 \\
(14.88)\end{array}$ & $\begin{array}{c}12.82 \\
(14.84)\end{array}$ \\
\hline
\end{tabular}




\begin{tabular}{|c|c|c|}
\hline Prefer not to say & $\begin{array}{c}38.52 \\
(32.87)\end{array}$ & $\begin{array}{c}36.50 \\
(28.09)\end{array}$ \\
\hline Pol. Left-right self-placement & $\begin{array}{l}-4.91 \\
(2.91)\end{array}$ & $\begin{array}{l}-6.67^{*} \\
(3.04)\end{array}$ \\
\hline Less redistribution & $\begin{array}{l}-4.08^{*} \\
(1.90)\end{array}$ & $\begin{array}{l}-3.61 \\
(2.49)\end{array}$ \\
\hline Respect for authority & $\begin{array}{l}-1.56 \\
(0.94)\end{array}$ & $\begin{array}{l}-2.59 \\
(1.76)\end{array}$ \\
\hline News consumption & $\begin{array}{c}3.06 \\
(4.36)\end{array}$ & $\begin{array}{c}3.35 \\
(4.88)\end{array}$ \\
\hline Most people can be trusted & $\begin{array}{l}13.10^{*} \\
(7.06)\end{array}$ & $\begin{array}{c}17.68 * * \\
(7.45)\end{array}$ \\
\hline \multicolumn{3}{|l|}{ Trust in government } \\
\hline Some of the time & $\begin{array}{l}-6.47 \\
(9.39)\end{array}$ & $\begin{array}{c}6.31 \\
(10.08)\end{array}$ \\
\hline Most of the time & $\begin{array}{c}2.41 \\
(10.44)\end{array}$ & $\begin{array}{c}12.18 \\
(15.46)\end{array}$ \\
\hline Just about always & $\begin{array}{c}13.68 \\
(31.20)\end{array}$ & $\begin{array}{c}37.51 \\
(28.20)\end{array}$ \\
\hline \multicolumn{3}{|l|}{ Employment Status } \\
\hline Working part-time (8-29hrs) & $\begin{array}{c}-8.94 \\
(14.48)\end{array}$ & $\begin{array}{l}-15.55 \\
(17.91)\end{array}$ \\
\hline Working part-time (less than 8hrs) & $\begin{array}{c}20.60 \\
(16.63)\end{array}$ & $\begin{array}{c}40.26 \\
(31.43)\end{array}$ \\
\hline On furlough & $\begin{array}{c}-4.93 \\
(17.40)\end{array}$ & $\begin{array}{c}1.04 \\
(18.18)\end{array}$ \\
\hline Unemployed & $\begin{array}{c}1.61 \\
(26.84)\end{array}$ & $\begin{array}{c}-3.15 \\
(23.40)\end{array}$ \\
\hline Full time university student & $\begin{array}{c}-3.64 \\
(17.60)\end{array}$ & $\begin{array}{c}-14.14 \\
(18.53)\end{array}$ \\
\hline Other full time student & $\begin{array}{c}13.38 \\
(30.58)\end{array}$ & $\begin{array}{c}32.22 \\
(45.78)\end{array}$ \\
\hline Retired & $\begin{array}{l}-21.86^{*} \\
(10.98)\end{array}$ & $\begin{array}{l}-29.36^{*} \\
(15.52)\end{array}$ \\
\hline Not in paid work & $\begin{array}{c}-5.01 \\
(13.90)\end{array}$ & $\begin{array}{c}-1.15 \\
(17.19)\end{array}$ \\
\hline Other & $\begin{array}{l}-26.72 \\
(24.79)\end{array}$ & $\begin{array}{c}0.69 \\
(30.49)\end{array}$ \\
\hline Education & $\begin{array}{c}-17.78^{* *} \\
(7.56)\end{array}$ & $\begin{array}{c}-23.30^{* *} \\
(7.73)\end{array}$ \\
\hline \multicolumn{3}{|l|}{ Religion } \\
\hline Church of England & $\begin{array}{c}8.93 \\
(12.93)\end{array}$ & $\begin{array}{c}6.70 \\
(14.03)\end{array}$ \\
\hline Roman Catholic & $\begin{array}{c}8.79 \\
(24.67)\end{array}$ & $\begin{array}{c}19.44 \\
(26.05)\end{array}$ \\
\hline Presbyterian & $\begin{array}{l}-15.23 \\
(23.09)\end{array}$ & $\begin{array}{l}-42.45 \\
(26.47)\end{array}$ \\
\hline Methodist & $\begin{array}{c}41.35 \\
(39.54)\end{array}$ & $\begin{array}{c}33.06 \\
(46.29)\end{array}$ \\
\hline Baptist & $\begin{array}{c}11.65 \\
(54.96)\end{array}$ & $\begin{array}{c}13.33 \\
(54.05)\end{array}$ \\
\hline United Reformed Church & $\begin{array}{c}84.90 * * \\
(27.15)\end{array}$ & $\begin{array}{c}96.67 * * \\
(34.31)\end{array}$ \\
\hline Free Presbyterian & $\begin{array}{l}-62.98 \\
(46.71)\end{array}$ & $\begin{array}{c}1.74 \\
(53.12)\end{array}$ \\
\hline Judaism & $\begin{array}{c}75.45 \\
(44.52)\end{array}$ & $\begin{array}{c}102.96 * * * \\
(20.86)\end{array}$ \\
\hline Hinduism & $\begin{array}{c}153.41 * * * \\
(40.12)\end{array}$ & $\begin{array}{c}184.51 * * \\
(64.74)\end{array}$ \\
\hline
\end{tabular}




\begin{tabular}{|c|c|c|}
\hline Islam & $\begin{array}{c}21.94 \\
(67.89)\end{array}$ & $\begin{array}{c}37.58 \\
(110.83)\end{array}$ \\
\hline Sikhism & $\begin{array}{l}-58.19 \\
(55.41)\end{array}$ & $\begin{array}{c}-4.29 \\
(59.520\end{array}$ \\
\hline Buddhism & $\begin{array}{l}-87.68^{*} \\
(45.42)\end{array}$ & $\begin{array}{c}-60.24 \\
(59.24)\end{array}$ \\
\hline Other & $\begin{array}{l}-52.27 \\
(30.95)\end{array}$ & $\begin{array}{l}-54.50 \\
(34.85)\end{array}$ \\
\hline Orthodox Christian & $\begin{array}{c}-2.39 \\
(38.02)\end{array}$ & $\begin{array}{c}13.12 \\
(42.75)\end{array}$ \\
\hline Pentecostal & $\begin{array}{c}17.00 \\
(27.85)\end{array}$ & $\begin{array}{c}19.01 \\
(32.21)\end{array}$ \\
\hline Evangelical & $\begin{array}{l}50.06^{*} \\
(26.73)\end{array}$ & $\begin{array}{l}54.63^{*} \\
(28.41)\end{array}$ \\
\hline Prefer not to say & $\begin{array}{l}-37.10 \\
(29.31)\end{array}$ & $\begin{array}{l}-76.26^{*} \\
(36.96)\end{array}$ \\
\hline \multicolumn{3}{|l|}{ How often going to church } \\
\hline Less often than once a year & $\begin{array}{c}-3.66 \\
(15.71)\end{array}$ & $\begin{array}{c}-6.08 \\
(14.77)\end{array}$ \\
\hline less often but at least once a year & $\begin{array}{l}-27.88 \\
(21.49)\end{array}$ & $\begin{array}{l}-20.94 \\
(23.03)\end{array}$ \\
\hline less often but at least twice a year & $\begin{array}{l}-32.04 \\
(24.37)\end{array}$ & $\begin{array}{c}-27.72 \\
(25.76)\end{array}$ \\
\hline less often but at least once a month & $\begin{array}{c}-8.72 \\
(29.93)\end{array}$ & $\begin{array}{l}-35.55 \\
(35.97)\end{array}$ \\
\hline $\begin{array}{c}\text { less often but at least once every two } \\
\text { weeks }\end{array}$ & $\begin{array}{l}-54.51 \\
(43.58)\end{array}$ & $\begin{array}{l}-75.30 \\
(49.76)\end{array}$ \\
\hline Once a week or more & $\begin{array}{c}18.86 \\
(30.48)\end{array}$ & $\begin{array}{c}9.41 \\
(35.78)\end{array}$ \\
\hline Varies too much to say & $\begin{array}{l}-65.65 * * \\
(29.32)\end{array}$ & $\begin{array}{l}-47.07 \\
(27.72)\end{array}$ \\
\hline Ability to cover living costs & $\begin{array}{c}2.20 \\
(3.46)\end{array}$ & $\begin{array}{c}4.74 \\
(3.82)\end{array}$ \\
\hline Earning due to pandemic & $\begin{array}{c}6.26 \\
(7.69)\end{array}$ & $\begin{array}{c}3.70 \\
(8.96)\end{array}$ \\
\hline How healthy felt recently & $\begin{array}{l}-1.66 \\
(1.07)\end{array}$ & $\begin{array}{l}-3.27 * \\
(1.47)\end{array}$ \\
\hline Risk-group dummy & $\begin{array}{c}1.18 \\
(11.58)\end{array}$ & $\begin{array}{c}-2.61 \\
(15.21)\end{array}$ \\
\hline Likelihood of contracted covid-19 & $\begin{array}{c}0.77 \\
(3.38)\end{array}$ & $\begin{array}{l}-0.08 \\
(4.67)\end{array}$ \\
\hline Risk seeking & $\begin{array}{c}-4.62 * * \\
(1.58)\end{array}$ & $\begin{array}{l}-2.55 \\
(1.90)\end{array}$ \\
\hline Patience & $\begin{array}{c}1.36 \\
(1.89)\end{array}$ & $\begin{array}{c}0.38 \\
(1.77)\end{array}$ \\
\hline Altruism & $\begin{array}{l}-0.01 \\
(0.02)\end{array}$ & $\begin{array}{l}-0.01 \\
(0.03)\end{array}$ \\
\hline Constant & $\begin{array}{l}282.99 * * * \\
(35.73)\end{array}$ & $\begin{array}{l}297.69 * * * \\
(48.98)\end{array}$ \\
\hline Observations & 1,041 & 815 \\
\hline R-squared & 0.1117 & 0.1309 \\
\hline
\end{tabular}

Notes: Estimates come from a linear regression. Regional clustering is done based on either the 12 regions of the UK, as defined by the ONS or the 50 states of the United States, as defined by the Census Bureau. Clustered standard errors are presented in parentheses. $* * * \mathrm{p}<0.01, * * \mathrm{p}<0.05, * \mathrm{p}<0.1$. 
Without death estimates Including death estimates

\begin{tabular}{|c|c|c|}
\hline Estimates of Covid-19 deaths & - & $\begin{array}{c}-0.00 * * * \\
(0.00)\end{array}$ \\
\hline Female & $\begin{array}{l}2.25 \\
(9.33)\end{array}$ & $\begin{array}{c}8.60 \\
(11.95)\end{array}$ \\
\hline Age (categories) & $\begin{array}{l}-5.00 \\
(5.72)\end{array}$ & $\begin{array}{l}-8.46 \\
(6.52)\end{array}$ \\
\hline Spanish, Hispanic or Latino dummy & $\begin{array}{c}7.92 \\
(20.46)\end{array}$ & $\begin{array}{c}15.86 \\
(19.54)\end{array}$ \\
\hline \multicolumn{3}{|l|}{ Race (multiple possible) } \\
\hline White & $\begin{array}{l}-31.96 \\
(22.51)\end{array}$ & $\begin{array}{c}-6.10 \\
(31.68)\end{array}$ \\
\hline Black or African-American & $\begin{array}{c}-95.73 * * * \\
(22.50)\end{array}$ & $\begin{array}{l}-20.37 \\
(26.66)\end{array}$ \\
\hline American Indian or Alaska Native & $\begin{array}{c}5.99 \\
(26.74)\end{array}$ & $\begin{array}{c}6.86 \\
(39.25)\end{array}$ \\
\hline Asian & $\begin{array}{l}-28.94 \\
(23.20)\end{array}$ & $\begin{array}{c}-4.42 \\
(27.25)\end{array}$ \\
\hline $\begin{array}{c}\text { Native Hawaiian or other Pacific } \\
\text { Islander }\end{array}$ & - & - \\
\hline Income & $\begin{array}{l}-2.28 \\
(2.00)\end{array}$ & $\begin{array}{l}-1.83 \\
(2.40)\end{array}$ \\
\hline \multicolumn{3}{|l|}{ Political Party } \\
\hline Republican Party & $\begin{array}{c}25.08 \\
(28.83)\end{array}$ & $\begin{array}{c}4.84 \\
(35.72)\end{array}$ \\
\hline Other & $\begin{array}{l}30.06^{*} \\
(15.10)\end{array}$ & $\begin{array}{c}27.50 \\
(21.72)\end{array}$ \\
\hline \multicolumn{3}{|l|}{2016 Vote } \\
\hline Didn't vote & $\begin{array}{l}-17.90 \\
(15.21)\end{array}$ & $\begin{array}{l}-21.10 \\
(21.21)\end{array}$ \\
\hline Donald Trump & $\begin{array}{l}-48.67 * * \\
(23.63)\end{array}$ & $\begin{array}{l}-36.25 \\
(29.35)\end{array}$ \\
\hline Prefer not to say & $\begin{array}{c}-8.15 \\
(20.52)\end{array}$ & $\begin{array}{l}-13.54 \\
(22.92)\end{array}$ \\
\hline Pol. Left-right self-placement & $\begin{array}{l}-5.21 \\
(4.35)\end{array}$ & $\begin{array}{l}-1.98 \\
(4.88)\end{array}$ \\
\hline Less redistribution & $\begin{array}{l}-8.03 * * * \\
(2.23)\end{array}$ & $\begin{array}{l}-9.86^{* * * *} \\
(2.91)\end{array}$ \\
\hline Respect for authority & $\begin{array}{c}0.98 \\
(2.48)\end{array}$ & $\begin{array}{c}0.84 \\
(3.31)\end{array}$ \\
\hline News consumption & $\begin{array}{c}12.10^{* * *} \\
(4.04)\end{array}$ & $\begin{array}{c}11.37 * * \\
(5.43)\end{array}$ \\
\hline Most people can be trusted & $\begin{array}{c}26.75^{* *} \\
(10.18)\end{array}$ & $\begin{array}{c}29.01 * * \\
(12.47)\end{array}$ \\
\hline \multicolumn{3}{|l|}{ Trust in government } \\
\hline Some of the time & $\begin{array}{c}-7.08 \\
(14.51)\end{array}$ & $\begin{array}{c}-5.11 \\
(18.21)\end{array}$ \\
\hline Most of the time & $\begin{array}{l}-10.80 \\
(21.93)\end{array}$ & $\begin{array}{c}-7.34 \\
(26.41)\end{array}$ \\
\hline Just about always & $\begin{array}{c}115.33 * * * \\
(31.60)\end{array}$ & $\begin{array}{c}139.94 * * * \\
(39.94)\end{array}$ \\
\hline \multicolumn{3}{|l|}{ Employment Status } \\
\hline Working part-time (8-29hrs) & 5.03 & 6.50 \\
\hline
\end{tabular}




\begin{tabular}{|c|c|c|}
\hline & $(17.58)$ & $(22.66)$ \\
\hline Working part-time (less than 8hrs) & $\begin{array}{c}8.11 \\
(22.29)\end{array}$ & $\begin{array}{c}8.44 \\
(34.85)\end{array}$ \\
\hline On furlough & $\begin{array}{l}-9.25 \\
(16.37)\end{array}$ & $\begin{array}{c}4.20 \\
(23.46)\end{array}$ \\
\hline Unemployed & $\begin{array}{c}25.29 \\
(16.89)\end{array}$ & $\begin{array}{c}10.60 \\
(21.56)\end{array}$ \\
\hline Full time university student & $\begin{array}{l}-46.97 \\
(30.68)\end{array}$ & $\begin{array}{c}-21.94 \\
(35.49)\end{array}$ \\
\hline Other full time student & $\begin{array}{c}9.36 \\
(47.58)\end{array}$ & $\begin{array}{c}45.66 \\
(70.64)\end{array}$ \\
\hline Retired & $\begin{array}{c}-6.86 \\
(21.54)\end{array}$ & $\begin{array}{c}-4.29 \\
(25.24)\end{array}$ \\
\hline Not in paid work & $\begin{array}{c}16.13 \\
(35.04)\end{array}$ & $\begin{array}{c}26.12 \\
(21.56)\end{array}$ \\
\hline Other & $\begin{array}{c}-19.90 \\
(35.04)\end{array}$ & $\begin{array}{c}-31.21 \\
(52.00)\end{array}$ \\
\hline Education & $\begin{array}{c}0.69 \\
(10.55)\end{array}$ & $\begin{array}{c}12.34 \\
(13.20)\end{array}$ \\
\hline \multicolumn{3}{|l|}{ Religion } \\
\hline Protestant & $\begin{array}{l}36.66^{*} \\
(18.56)\end{array}$ & $\begin{array}{l}40.13 * \\
(22.15)\end{array}$ \\
\hline Roman Catholic & $\begin{array}{c}2.83 \\
(20.63)\end{array}$ & $\begin{array}{c}-6.94 \\
(26.14)\end{array}$ \\
\hline Mormon & $\begin{array}{l}-21.25 \\
(54.39)\end{array}$ & $\begin{array}{c}-116.65^{* *} \\
(51.53)\end{array}$ \\
\hline Other Christian & $\begin{array}{c}21.86 \\
(19.34)\end{array}$ & $\begin{array}{c}11.59 \\
(31.43)\end{array}$ \\
\hline Jewish & $\begin{array}{l}-15.28 \\
(38.08)\end{array}$ & $\begin{array}{c}-15.04 \\
(41.58)\end{array}$ \\
\hline Muslim & $\begin{array}{c}75.63 * * * \\
(25.89)\end{array}$ & $\begin{array}{l}91.22 * * \\
(39.26)\end{array}$ \\
\hline Other non-Christian & $\begin{array}{l}-23.19 \\
(26.16)\end{array}$ & $\begin{array}{c}-4.21 \\
(33.58)\end{array}$ \\
\hline Prefer not to say & $\begin{array}{l}-88.50 \\
(60.51)\end{array}$ & $\begin{array}{c}-129.40^{* *} \\
(50.27)\end{array}$ \\
\hline \multicolumn{3}{|l|}{ How often going to church } \\
\hline Less often than once a year & $\begin{array}{c}13.57 \\
(13.37)\end{array}$ & $\begin{array}{c}12.20 \\
(18.17)\end{array}$ \\
\hline less often but at least once a year & $\begin{array}{l}-20.98 \\
(26.86)\end{array}$ & $\begin{array}{c}4.78 \\
(38.74)\end{array}$ \\
\hline less often but at least twice a year & $\begin{array}{c}-9.06 \\
(30.55)\end{array}$ & $\begin{array}{l}-21.98 \\
(41.92)\end{array}$ \\
\hline less often but at least once a month & $\begin{array}{c}11.80 \\
(28.39)\end{array}$ & $\begin{array}{c}0.22 \\
(33.08)\end{array}$ \\
\hline $\begin{array}{c}\text { less often but at least once every two } \\
\text { weeks }\end{array}$ & $\begin{array}{c}48.31 \\
(33.07)\end{array}$ & $\begin{array}{c}50.05 \\
(32.05)\end{array}$ \\
\hline Once a week or more & $\begin{array}{c}27.12 \\
(20.40)\end{array}$ & $\begin{array}{c}9.84 \\
(26.73)\end{array}$ \\
\hline Ability to cover living costs & $\begin{array}{l}5.05^{*} \\
(2.82)\end{array}$ & $\begin{array}{c}5.14 \\
(3.71)\end{array}$ \\
\hline Earning due to pandemic & $\begin{array}{c}11.71 \\
(10.58)\end{array}$ & $\begin{array}{l}10.64 \\
(14.55)\end{array}$ \\
\hline How healthy felt recently & $\begin{array}{c}0.89 \\
(2.48)\end{array}$ & $\begin{array}{l}-1.79 \\
(3.44)\end{array}$ \\
\hline Risk-group dummy & $\begin{array}{c}21.28 \\
(13.44)\end{array}$ & $\begin{array}{c}17.53 \\
(17.17)\end{array}$ \\
\hline
\end{tabular}




\begin{tabular}{ccc}
\hline Likelihood of contracted covid-19 & -2.62 & -6.56 \\
Risk seeking & $(4.71)$ & $(6.50)$ \\
\hline \multirow{2}{*}{ Patience } & 0.17 & 2.11 \\
& $(1.64)$ & $(2.20)$ \\
\hline \multirow{2}{*}{ Altruism } & -2.78 & -2.17 \\
& $(2.28)$ & $(2.81)$ \\
\hline \multirow{2}{*}{ Constant } & 0.01 & $(0.03)$ \\
\hline \multirow{2}{*}{ Observations } & $(0.02)$ & $333.15^{* * *}$ \\
\hline \multirow{2}{*}{ R-squared } & $397.82 * * *$ & $(79.77)$ \\
\hline \hline
\end{tabular}

Notes: Estimates come from a linear regression. Regional clustering is done based on either the 12 regions of the UK, as defined by the ONS or the 50 states of the United States, as defined by the Census Bureau. Clustered standard errors are presented in parentheses. $* * * \mathrm{p}<0.01, * * \mathrm{p}<0.05, * \mathrm{p}<0.1$.

\section{h. Additional subgroup analysis of main treatment effects}

In addition to the analysis of our main treatment effects, we tested for interactions of treatment effects with demographic variables. Table 15 and table 16 report two significant interactions. Table 15 reports treatment effects in the UK interacted with age and table 16 reports treatment effects in the US interacted with redistributive preferences. In the UK we find that respondents over the age of 50 who were assigned to the wealth treatment were more likely to move away from the maximum value of life post-treatment. In the US we find that people who support more redistribution significantly reduce their implied value of life when assigned to the health treatment. This effect is driven by those who underestimate deaths. 
UK

\begin{tabular}{|c|c|}
\hline Treatment & \\
\hline Health treatment (TI) & $\begin{array}{l}-0.41 \\
(0.69)\end{array}$ \\
\hline Wealth treatment (T2) & $\begin{array}{l}-1.43 \\
(1.22)\end{array}$ \\
\hline \multicolumn{2}{|l|}{ Age } \\
\hline $25-34$ & $\begin{array}{l}-0.89 \\
(0.88)\end{array}$ \\
\hline $35-49$ & $\begin{array}{c}0.10 \\
(0.79)\end{array}$ \\
\hline $50-64$ & $\begin{array}{c}0.10 \\
(0.36)\end{array}$ \\
\hline $65+$ & $\begin{array}{l}-0.17 \\
(0.39)\end{array}$ \\
\hline \multicolumn{2}{|l|}{ Treatments x Age } \\
\hline$T 1 \times 25-34$ & $\begin{array}{c}1.20 \\
(1.08)\end{array}$ \\
\hline$T 1 \times 35-49$ & $\begin{array}{c}0.42 \\
(0.78)\end{array}$ \\
\hline$T 1 \times 50-64$ & $\begin{array}{c}0.87 \\
(0.84)\end{array}$ \\
\hline$T 1 \times 65+$ & $\begin{array}{c}0.49 \\
(0.49)\end{array}$ \\
\hline$T 2 \times 25-34$ & $\begin{array}{c}2.13 \\
(1.39)\end{array}$ \\
\hline$T 2 \times 35-49$ & $\begin{array}{c}1.55 \\
(1.56)\end{array}$ \\
\hline$T 2 \times 50-64$ & $\begin{array}{l}1.87^{*} \\
(1.03)\end{array}$ \\
\hline$T 2 \times 65+$ & $\begin{array}{l}1.87^{*} \\
(0.97)\end{array}$ \\
\hline Constant & $\begin{array}{c}-3.26^{* * *} \\
(0.51)\end{array}$ \\
\hline Observations & 2,399 \\
\hline Pseudo R-squared & 0.0159 \\
\hline
\end{tabular}

Notes: Estimates come from a logistic regression. Regional clustering is done based on either the 12 regions of the UK, as defined by the ONS or the 50 states of the United States, as defined by the Census Bureau. Clustered standard errors are presented in parentheses. ${ }^{* * *} \mathrm{p}<0.01,{ }^{* *} \mathrm{p}<0.05,{ }^{*} \mathrm{p}<0.1$. 
US

US (only those that underestimated deaths)

\begin{tabular}{lcc}
\hline Treatment & & \\
Health treatment (T1) & $\left(12.15^{* *}\right.$ & $28.17^{*}$ \\
& $15.74^{*}$ & $(14.01)$ \\
Wealth treatment (T2) & $(9.02)$ & 19.58 \\
Redistributive Preferences & 2.94 & $(18.59)$ \\
More redistribution & $(3.75)$ & -1.46 \\
& 3.82 & $(5.16)$ \\
Less redistribution & $(8.21)$ & 4.91 \\
Treatments x Redistributive & & $(5.43)$ \\
Preferences & & \\
\hline & $-28.17^{* *}$ & $-30.66^{* *}$ \\
T1 x more redistribution & $(12.13)$ & $(13.29)$ \\
\hline & $-31.88^{*}$ & -22.16 \\
T1 x less redistribution & $(17.11)$ & $(22.33)$ \\
\hline & -13.49 & -15.44 \\
$T 2 x$ more redistribution & $(9.77)$ & $(20.28)$ \\
\hline & -14.50 & -24.57 \\
T2 $x$ less redistribution & $(14.26)$ & $(20.70)$ \\
\hline & -4.75 & -2.97 \\
Constant & $(3.32)$ & $(2.45)$ \\
Observations & 1,263 & 698 \\
R-squared & 0.0060 & 0.0135 \\
\hline \hline
\end{tabular}

Notes: Estimates come from a linear regression. Regional clustering is done based on either the 12 regions of the UK, as defined by the ONS or the 50 states of the United States, as defined by the Census Bureau. Clustered standard errors are presented in parentheses. ${ }^{* * *} \mathrm{p}<0.01,{ }^{* *} \mathrm{p}<0.05, * \mathrm{p}<0.1$. The categorical redistribution variable is based on demographic question D9 and coded as "more redistribution" if respondent $i$ indicated a value of below 5 , as "less redistribution" if respondent $i$ indicated a value of above 5 and as "indifferent" for a value of 0 .

\section{Robustness}

\section{a. Preference stability in control group}

To have a preference ordering, there must be only one switch point each time a person faces the eight binary decisions. There are some people who exhibit more than one switch point, either the first or the second time they confront the binary options. We typically ignore a person's choices when this happens. Those respondents - as well as those who did not choose a switch point in either the first or second round of the experiment - are coded as missing in our main variables.

To interpret our treatment effects as effects on preferences, it matters whether we can reasonably assume that people who have a single switch point on each set also have a 
preference ordering. This is not necessarily the case because anyone who chose a switch point randomly would satisfy the condition of only switching once. And if random selection explained their switch point then the treatment effect would be better interpreted as some interaction with the randomization process. To test for this possibility, we analyze the stability of preferences in the control group where no treatment effect could occur. We have evidence of such consistency of choice between the first and second time these decisions are made, and this would be unusual if people chose the switch point randomly (805 of 1,006 control grouprespondents who chose a switch point both pre- and post-treatment expressed stable preferences). In fact, the probability of choosing the same switch point twice if the choice of switch point on each occasion was random would be $1 / 8$ (i.e. $8 \times 1 / 64$ ), while we have $80 \%$ consistent choices.

The number of preference-based choosers might be plausibly calculated in the following way by allowing for strict preference followers, 'fuzzy' ones (defined below) and random choosers.

'Fuzzy' preference followers are people that know the region they like but not the precise point: they cannot distinguish between adjacent switching points and so toss a coin. For example, if someone thinks they should switch at decision 6 or decision 7, they toss a coin and might choose 7 . When asked again they toss the coin again and there is a 50\% chance they choose 7 again and a $50 \%$ chance they now choose 6 . Thus, there is a $50 \%$ chance that we observe one downward movement. Alternatively, they could have chosen 6 in first place; then they have an equal chance of staying at 6 or moving up to 7 in the second decision. For this person there is a $50 \%$ chance they pick the same, a $25 \%$ chance that they move up and a $25 \%$ chance that they move down. We have 136 respondent who change by one decision point, which would arise if there were 272 people who had fuzzy preferences as defined above.

However, some people who just choose randomly would also change their switch point by one position $=7 / 32$. Since $1 / 8$ of these random choosers would select the same point, it follows that $21 / 32$ of the random choosers would move their decision by more than one point. We have 65 choices that move by more than one switch point. This would imply 99 random choosers in our sample. This being the case, the random choosers would also account for 22 of the observations of one switch point changes. We had 136 observations with one switch and so that leaves 114 of these choices to be accounted for by respondents with fuzzy preferences.

These overall 228 respondents with fuzzy preferences would produce 114 of the consistent choices we observe (and we would expect 12 of these observations to come from the random choosers). Thus, our residual number of genuine preference-based choosers is 679, with 228 fuzzy preference choosers and 99 random choosers. Overall, our sample therefore consists of $90 \%$ either consistent or fuzzy preference-choosers.

\section{b. Main treatment effects with demographic controls}

To further test the robustness of our results we estimated all our main treatment effects with the within subject analysis and additionally included our demographic covariates. The results of this analysis are reported in tables 17-20. All our main treatment results hold. 


\begin{tabular}{|c|c|c|c|c|}
\hline & \multicolumn{4}{|c|}{ Main treatment effects } \\
\hline & $\begin{array}{c}\text { Down from } \\
\text { max. VoL } \\
\text { (UK) }\end{array}$ & $\begin{array}{c}\text { Up to } \\
\text { max. VoL } \\
(\mathrm{UK})\end{array}$ & $\begin{array}{c}\text { Down from } \\
\text { max. VoL } \\
\text { (US) }\end{array}$ & $\begin{array}{l}\text { Up to max. } \\
\text { VoL (US) }\end{array}$ \\
\hline \multicolumn{5}{|l|}{ Treatment } \\
\hline Health treatment (T1) & $\begin{array}{c}0.797 \\
(0.640)\end{array}$ & $\begin{array}{l}-0.995^{*} \\
(0.585)\end{array}$ & $\begin{array}{c}0.581 \\
(0.662)\end{array}$ & $\begin{array}{c}0.333 \\
(0.557)\end{array}$ \\
\hline Wealth treatment (T2) & $\begin{array}{c}0.741 * * \\
(0.310)\end{array}$ & $\begin{array}{l}-0.469 \\
(0.887)\end{array}$ & $\begin{array}{c}0.241 \\
(0.604)\end{array}$ & $\begin{array}{c}-0.011 \\
(0.544)\end{array}$ \\
\hline Constant & $\begin{array}{c}-4.094 * * \\
(1.602)\end{array}$ & $\begin{array}{c}13.881 * * * \\
(3.657)\end{array}$ & $\begin{array}{l}-0.907 \\
(2.800)\end{array}$ & $\begin{array}{c}-8.221 * * \\
(3.323)\end{array}$ \\
\hline Demographic controls & $\checkmark$ & $\checkmark$ & $\checkmark$ & $\checkmark$ \\
\hline Regional clustering & $\checkmark$ & $\checkmark$ & $\checkmark$ & $\checkmark$ \\
\hline Observations & 617 & 732 & 835 & 764 \\
\hline Pseudo R-squared & 0.142 & 0.380 & 0.169 & 0.159 \\
\hline
\end{tabular}

Notes: Estimates come from a logistic regression. Regional clustering is done based on either the 12 regions of the UK, as defined by the ONS or the 50 states of the United States, as defined by the Census Bureau. Clustered standard errors are presented in parentheses. ${ }^{* * *} \mathrm{p}<0.01, * * \mathrm{p}<0.05, * \mathrm{p}<0.1$.

Table 18: Main treatment effects without interactions (Switch point)

\begin{tabular}{lcccc}
\hline & \multicolumn{5}{c}{ Main treatment effects } \\
& $\begin{array}{c}\text { Switch up } \\
\text { (UK) }\end{array}$ & $\begin{array}{c}\text { Switch } \\
\text { down (UK) }\end{array}$ & $\begin{array}{c}\text { Switch up } \\
\text { (US) }\end{array}$ & $\begin{array}{c}\text { Switch } \\
\text { down (US) }\end{array}$ \\
\hline \hline & & & \\
\hline Treatment & -0.143 & 0.047 & $0.282^{*}$ & 0.145 \\
Health treatment (T1) & $(0.209)$ & $(0.197)$ & $(0.152)$ & $(0.199)$ \\
\hline & 0.001 & 0.084 & 0.070 & 0.215 \\
Wealth treatment (T2) & $(0.123)$ & $(0.292)$ & $(0.169)$ & $(0.203)$ \\
\hline & -0.790 & $-3.605^{* * *}$ & $-1.180^{*}$ & $-2.265^{* * *}$ \\
Constant & $(0.682)$ & $(0.934)$ & $(0.676)$ & $(0.783)$ \\
\hline \hline Demographic controls & $\checkmark$ & $\checkmark$ & $\checkmark$ & $\checkmark$ \\
\hline Regional clustering & $\checkmark$ & $\checkmark$ & $\checkmark$ & $\checkmark$ \\
\hline Observations & 1,419 & 1,383 & 1,619 & 1,600 \\
\hline Pseudo R-squared & 0.050 & 0.072 & 0.042 & 0.057 \\
\hline \hline
\end{tabular}

Notes: Estimates come from a logistic regression. Regional clustering is done based on either the 12 regions of the UK, as defined by the ONS or the 50 states of the United States, as defined by the Census Bureau. Clustered standard errors are presented in parentheses. $* * * \mathrm{p}<0.01, * * \mathrm{p}<0.05, * \mathrm{p}<0.1$. 


\section{Main treatment effects}

Down from Up to Down from
max. VoL max. VoL max. VoL Up to max.

\begin{tabular}{|c|c|c|c|c|}
\hline & $(\mathrm{UK})$ & $(\mathrm{UK})$ & (US) & VoL (US) \\
\hline \multicolumn{5}{|l|}{ Treatment } \\
\hline Health treatment (T1) & $\begin{array}{c}1.142 \\
(0.970)\end{array}$ & $\begin{array}{c}-1.535^{*} \\
(0.901)\end{array}$ & $\begin{array}{c}0.913 \\
(0.675)\end{array}$ & $\begin{array}{c}0.224 \\
(0.663)\end{array}$ \\
\hline Wealth treatment (T2) & $\begin{array}{c}-0.492 \\
(0.439)\end{array}$ & $\begin{array}{l}-0.240 \\
(1.060)\end{array}$ & $\begin{array}{l}-0.502 \\
(0.746)\end{array}$ & $\begin{array}{l}-0.084 \\
(0.582)\end{array}$ \\
\hline \multicolumn{5}{|l|}{ Income Estimate } \\
\hline T2 $x$ Underestimate & $\begin{array}{c}1.982 * * * \\
(0.481)\end{array}$ & $\begin{array}{c}-0.537 \\
(0.812)\end{array}$ & $\begin{array}{c}1.828 * * \\
(0.759)\end{array}$ & $\begin{array}{c}0.285 \\
(0.818)\end{array}$ \\
\hline T2 $x$ Overestimate & omitted & omitted & omitted & omitted \\
\hline \multicolumn{5}{|l|}{ Death Estimate } \\
\hline T1 $x$ Underestimate & $\begin{array}{l}-0.423 \\
(1.153)\end{array}$ & $\begin{array}{l}1.793^{*} \\
(0.998)\end{array}$ & $\begin{array}{l}-0.861 \\
(0.636)\end{array}$ & $\begin{array}{c}0.230 \\
(0.669)\end{array}$ \\
\hline T1 $x$ Overestimate & $\begin{array}{l}-0.392 \\
(1.054)\end{array}$ & omitted & omitted & omitted \\
\hline Constant & $\begin{array}{c}-4.264 * * \\
(1.801)\end{array}$ & $\begin{array}{c}14.281 * * * \\
(3.477)\end{array}$ & $\begin{array}{c}-1.048 \\
(2.845)\end{array}$ & $\begin{array}{c}-8.240^{* *} \\
(3.344)\end{array}$ \\
\hline Demographic controls & $\checkmark$ & $\checkmark$ & $\checkmark$ & $\checkmark$ \\
\hline Regional clustering & $\checkmark$ & $\checkmark$ & $\checkmark$ & $\checkmark$ \\
\hline Observations & 615 & 600 & 833 & 762 \\
\hline Pseudo R-squared & 0.174 & 0.389 & 0.194 & 0.160 \\
\hline
\end{tabular}

Notes: Estimates come from a logistic regression. Regional clustering is done based on either the 12 regions of the UK, as defined by the ONS or the 50 states of the United States, as defined by the Census Bureau. Clustered standard errors are presented in parentheses. $* * * \mathrm{p}<0.01, * * \mathrm{p}<0.05, * \mathrm{p}<0.1$. 


\begin{tabular}{|c|c|c|c|c|}
\hline & \multicolumn{4}{|c|}{ Main treatment effects } \\
\hline & $\begin{array}{c}\text { Switch up } \\
\text { (UK) }\end{array}$ & $\begin{array}{c}\text { Switch } \\
\text { down (UK) }\end{array}$ & $\begin{array}{c}\text { Switch up } \\
\text { (US) }\end{array}$ & $\begin{array}{c}\text { Switch } \\
\text { down (US) } \\
\end{array}$ \\
\hline \multicolumn{5}{|l|}{ Treatment } \\
\hline Health treatment & $\begin{array}{c}-0.385 \\
(0.401)\end{array}$ & $\begin{array}{c}-0.739 \\
(0.606)\end{array}$ & $\begin{array}{c}0.098 \\
(0.171)\end{array}$ & $\begin{array}{c}0.284 \\
(0.236)\end{array}$ \\
\hline Wealth treatment & $\begin{array}{c}0.779 \\
(0.977)\end{array}$ & $\begin{array}{c}0.154 \\
(1.151)\end{array}$ & $\begin{array}{c}0.348 \\
(1.007)\end{array}$ & $\begin{array}{c}0.240 \\
(0.229)\end{array}$ \\
\hline \multicolumn{5}{|l|}{ Income Estimate } \\
\hline T2 $x$ Underestimate & $\begin{array}{c}-0.724 \\
(1.068)\end{array}$ & $\begin{array}{c}-0.254 \\
(1.079)\end{array}$ & $\begin{array}{l}-0.315 \\
(1.019)\end{array}$ & $\begin{array}{l}-0.050 \\
(0.373)\end{array}$ \\
\hline T2 $\times$ Overestimate & $\begin{array}{c}-0.901 \\
(0.992)\end{array}$ & $\begin{array}{c}0.051 \\
(1.067)\end{array}$ & $\begin{array}{c}-0.282 \\
(1.034)\end{array}$ & omitted \\
\hline \multicolumn{5}{|l|}{ Death Estimate } \\
\hline T1 $x$ Underestimate & $\begin{array}{c}0.165 \\
(0.432)\end{array}$ & $\begin{array}{c}0.693 \\
(0.652)\end{array}$ & $\begin{array}{l}0.373^{*} \\
(0.202)\end{array}$ & $\begin{array}{c}-0.292 \\
(0.287)\end{array}$ \\
\hline T1 x Overestimate & $\begin{array}{c}0.384 \\
(0.404)\end{array}$ & $\begin{array}{c}1.070 \\
(0.654)\end{array}$ & omitted & omitted \\
\hline Constant & $\begin{array}{c}-0.865 \\
(0.622)\end{array}$ & $\begin{array}{c}-3.664 * * * \\
(0.892)\end{array}$ & $\begin{array}{c}-1.175^{*} \\
(0.678)\end{array}$ & $\begin{array}{c}-2.160 * * * \\
(0.812)\end{array}$ \\
\hline Demographic controls & $\checkmark$ & $\checkmark$ & $\checkmark$ & $\checkmark$ \\
\hline Regional clustering & $\checkmark$ & $\checkmark$ & $\checkmark$ & $\checkmark$ \\
\hline Observations & 1,412 & 1,377 & 1,609 & 1,585 \\
\hline Pseudo R-squared & 0.054 & 0.077 & 0.045 & 0.058 \\
\hline
\end{tabular}

Notes: Estimates come from a logistic regression. Regional clustering is done based on either the 12 regions of the UK, as defined by the ONS or the 50 states of the United States, as defined by the Census Bureau. Clustered standard errors are presented in parentheses. $* * * \mathrm{p}<0.01, * * \mathrm{p}<0.05, * \mathrm{p}<0.1$.

\section{c. Main treatment effects with alternative coding of outcome variables}

Our main analysis coded each of the main outcome variables as 0 if either, subjects did not move from their original switch point post-treatment or, if they moved in the opposite direction to the captured direction of the outcome variable. To check the robustness of our estimates we estimated our models included outcome variables only then equal to 0 , when subjects did not move from their original switch point post-treatment. Tables 21-24 report the main treatment effects with this alternative coding of the outcome variables. The main results of our analysis hold. 


\begin{tabular}{|c|c|c|c|c|}
\hline & \multicolumn{4}{|c|}{ Main treatment effects } \\
\hline & $\begin{array}{c}\text { Down from } \\
\text { max. VoL } \\
\text { (UK) }\end{array}$ & $\begin{array}{l}\text { Up to } \\
\text { max. VoL } \\
\text { (UK) }\end{array}$ & $\begin{array}{l}\text { Down from } \\
\text { max. VoL } \\
\text { (US) }\end{array}$ & $\begin{array}{l}\text { Up to max. } \\
\text { VoL (US) }\end{array}$ \\
\hline Treatment & & & & \\
\hline Health treatment (T1) & $\begin{array}{c}0.366 \\
(0.361)\end{array}$ & $\begin{array}{l}-0.976 \\
(0.594)\end{array}$ & $\begin{array}{c}0.151 \\
(0.427)\end{array}$ & $\begin{array}{c}0.438 \\
(0.461)\end{array}$ \\
\hline Wealth treatment (T2) & $\begin{array}{l}0.511^{*} \\
(0.305)\end{array}$ & $\begin{array}{l}-0.105 \\
(0.477)\end{array}$ & $\begin{array}{l}-0.500 \\
(0.552)\end{array}$ & $\begin{array}{c}0.297 \\
(0.526)\end{array}$ \\
\hline Constant & $\begin{array}{c}-3.684 * * * \\
(0.220)\end{array}$ & $\begin{array}{c}-3.497 * * * \\
(0.340)\end{array}$ & $\begin{array}{c}-3.583 * * * \\
(0.309)\end{array}$ & $\begin{array}{c}-3.971 * * * \\
(0.341)\end{array}$ \\
\hline Regional clustering & $\checkmark$ & $\checkmark$ & $\checkmark$ & $\checkmark$ \\
\hline Observations & 1,628 & 1,607 & 1,351 & 1,344 \\
\hline Pseudo R-squared & 0.005 & 0.015 & 0.007 & 0.003 \\
\hline
\end{tabular}

Notes: Estimates come from a logistic regression. Regional clustering is done based on either the 12 regions of the UK, as defined by the ONS or the 50 states of the United States, as defined by the Census Bureau. Clustered standard errors are presented in parentheses. ${ }^{* * *} \mathrm{p}<0.01,{ }^{* *} \mathrm{p}<0.05,{ }^{*} \mathrm{p}<0.1$.

Table 22: Main treatment effects without interactions (Switch point) - alt. variable

\begin{tabular}{lcccc}
\hline \multicolumn{5}{c}{ Main treatment effects } \\
& $\begin{array}{c}\text { Switch } \\
\text { Switch Up } \\
\text { (UK) }\end{array}$ & $\begin{array}{c}\text { Down } \\
\text { (UK) }\end{array}$ & $\begin{array}{c}\text { Switch Up } \\
\text { (US) }\end{array}$ & $\begin{array}{c}\text { Switch } \\
\text { Down (US) }\end{array}$ \\
& \multicolumn{5}{c}{} \\
\hline \hline Treatment & -0.225 & -0.117 & $0.259^{* *}$ & 0.159 \\
\hline Health treatment (T1) & $(0.193)$ & $(0.122)$ & $(0.129)$ & $(0.152)$ \\
\hline & -0.114 & 0.106 & 0.067 & 0.149 \\
Wealth treatment (T2) & $(0.116)$ & $(0.182)$ & $(0.140)$ & $(0.151)$ \\
\hline & $-1.006^{* * *}$ & $-1.728^{* * *}$ & $-1.330^{* * *}$ & $-1.833 * * *$ \\
Constant & $(0.110)$ & $(0.090)$ & $(0.110)$ & $(0.087)$ \\
\hline \hline Regional clustering & $\checkmark$ & $\checkmark$ & $\checkmark$ & $\checkmark$ \\
\hline Observations & 2,114 & 1,880 & 1,973 & 1,801 \\
\hline Pseudo R-squared & 0.001 & 0.001 & 0.002 & 0.001 \\
\hline \hline
\end{tabular}

Notes: Estimates come from a logistic regression. Regional clustering is done based on either the 12 regions of the UK, as defined by the ONS or the 50 states of the United States, as defined by the Census Bureau. Clustered standard errors are presented in parentheses. ${ }^{* * *} \mathrm{p}<0.01,{ }^{* *} \mathrm{p}<0.05,{ }^{*} \mathrm{p}<0.1$. 
Table 23: Main treatment effects with interactions (Top Value of Life) - alt. variable

\section{Main treatment effects}

\begin{tabular}{|c|c|c|c|c|}
\hline & $\begin{array}{c}\text { Down from } \\
\text { max. VoL } \\
(\mathrm{UK}) \\
\end{array}$ & $\begin{array}{c}\text { Up to } \\
\text { max. VoL } \\
(\mathrm{UK}) \\
\end{array}$ & $\begin{array}{c}\text { Down from } \\
\text { max. VoL } \\
\text { (US) } \\
\end{array}$ & $\begin{array}{l}\text { Up to max. } \\
\text { VoL (US) } \\
\end{array}$ \\
\hline \multicolumn{5}{|l|}{ Treatment } \\
\hline Health treatment (T1) & $\begin{array}{l}0.739^{*} \\
(0.442)\end{array}$ & $\begin{array}{l}-0.427 \\
(1.219)\end{array}$ & $\begin{array}{c}0.226 \\
(0.488)\end{array}$ & $\begin{array}{c}0.474 \\
(0.494)\end{array}$ \\
\hline Wealth treatment (T2) & $\begin{array}{l}-0.041 \\
(0.345)\end{array}$ & $\begin{array}{l}-0.196 \\
(0.575)\end{array}$ & $\begin{array}{c}-1.334 * \\
(0.685)\end{array}$ & $\begin{array}{c}0.310 \\
(0.539)\end{array}$ \\
\hline \multicolumn{5}{|l|}{ Income Estimate } \\
\hline T2 $x$ Underestimate & $\begin{array}{c}1.115^{* * *} * \\
(0.221)\end{array}$ & $\begin{array}{c}0.261 \\
(0.573)\end{array}$ & $\begin{array}{c}1.885 * * * \\
(0.671)\end{array}$ & $\begin{array}{c}-0.031 \\
(0.747)\end{array}$ \\
\hline T2 $x$ Overestimate & omitted & omitted & omitted & omitted \\
\hline \multicolumn{5}{|l|}{ Death Estimate } \\
\hline T1 $x$ Underestimate & $\begin{array}{c}-0.628 \\
(0.667)\end{array}$ & $\begin{array}{c}-1.763 * * * \\
(0.130)\end{array}$ & $\begin{array}{l}-0.167 \\
(0.540)\end{array}$ & $\begin{array}{l}-0.076 \\
(0.586)\end{array}$ \\
\hline T1 $x$ Overestimate & $\begin{array}{l}-0.189 \\
(0.412)\end{array}$ & $\begin{array}{c}0.045 \\
(1.195)\end{array}$ & omitted & Omitted \\
\hline Constant & $\begin{array}{c}-3.684 * * * \\
(0.220) \\
\end{array}$ & $\begin{array}{c}-3.583 * * * \\
(0.309) \\
\end{array}$ & $\begin{array}{c}-3.497 * * * \\
(0.340) \\
\end{array}$ & $\begin{array}{c}-3.971 * * * \\
(0.341) \\
\end{array}$ \\
\hline Regional clustering & $\checkmark$ & $\checkmark$ & $\checkmark$ & $\checkmark$ \\
\hline Observations & 1,621 & 1,600 & 1,348 & 1,341 \\
\hline Pseudo R-squared & 0.020 & 0.027 & 0.027 & 0.003 \\
\hline
\end{tabular}

Notes: Estimates come from a logistic regression. Regional clustering is done based on either the 12 regions of the UK, as defined by the ONS or the 50 states of the United States, as defined by the Census Bureau. Clustered standard errors are presented in parentheses. ${ }^{* * *} \mathrm{p}<0.01,{ }^{* *} \mathrm{p}<0.05,{ }^{*} \mathrm{p}<0.1$. 


\section{Main treatment effects}

Switch

\begin{tabular}{cccc}
$\begin{array}{c}\text { Switch Up } \\
(\mathrm{UK})\end{array}$ & $\begin{array}{c}\text { Down } \\
(\mathrm{UK})\end{array}$ & $\begin{array}{c}\text { Switch Up } \\
(\mathrm{US})\end{array}$ & $\begin{array}{c}\text { Switch } \\
\text { Down (US) }\end{array}$ \\
\hline
\end{tabular}

\begin{tabular}{|c|c|c|c|c|}
\hline & & & & \\
\hline \multicolumn{5}{|l|}{ Treatment } \\
\hline Health treatment (T1) & $\begin{array}{l}-0.224 \\
(0.377)\end{array}$ & $\begin{array}{l}-0.908 \\
(0.579)\end{array}$ & $\begin{array}{c}0.129 \\
(0.148)\end{array}$ & $\begin{array}{c}0.224 \\
(0.207)\end{array}$ \\
\hline Wealth treatment (T2) & $\begin{array}{c}1.099 \\
(0.681)\end{array}$ & $\begin{array}{c}0.172 \\
(0.965)\end{array}$ & $\begin{array}{l}-0.862 \\
(1.091)\end{array}$ & $\begin{array}{c}0.113 \\
(0.173)\end{array}$ \\
\hline \multicolumn{5}{|l|}{ Income Estimate } \\
\hline T2 $x$ Underestimate & $\begin{array}{l}-1.107 \\
(0.761)\end{array}$ & $\begin{array}{l}-0.117 \\
(0.983)\end{array}$ & $\begin{array}{c}0.927 \\
(1.086)\end{array}$ & $\begin{array}{c}0.213 \\
(0.244)\end{array}$ \\
\hline T2 $x$ Overestimate & $\begin{array}{c}-1.342^{* *} \\
(0.652)\end{array}$ & $\begin{array}{l}-0.036 \\
(0.977)\end{array}$ & $\begin{array}{c}0.947 \\
(1.104)\end{array}$ & omitted \\
\hline \multicolumn{5}{|l|}{ Death Estimate } \\
\hline T1 $x$ Underestimate & $\begin{array}{l}-0.137 \\
(0.319)\end{array}$ & $\begin{array}{c}0.657 \\
(0.586)\end{array}$ & $\begin{array}{c}0.295 \\
(0.187)\end{array}$ & $\begin{array}{l}-0.149 \\
(0.243)\end{array}$ \\
\hline T1 $x$ Overestimate & $\begin{array}{c}0.208 \\
(0.308)\end{array}$ & $\begin{array}{l}1.090^{*} \\
(0.628)\end{array}$ & omitted & omitted \\
\hline Constant & $\begin{array}{c}-1.011 * * * \\
(0.108) \\
\end{array}$ & $\begin{array}{c}-1.722 * * * \\
(0.090) \\
\end{array}$ & $\begin{array}{c}-1.345^{* * *} \\
(0.110) \\
\end{array}$ & $\begin{array}{c}-1.828 * * * \\
(0.088) \\
\end{array}$ \\
\hline Regional clustering & $\checkmark$ & $\checkmark$ & $\checkmark$ & $\checkmark$ \\
\hline Observations & 2,095 & 1,868 & 1,957 & 1,784 \\
\hline Pseudo R-squared & 0.005 & 0.005 & 0.004 & 0.002 \\
\hline
\end{tabular}

Notes: Estimates come from a logistic regression. Regional clustering is done based on either the 12 regions of the UK, as defined by the ONS or the 50 states of the United States, as defined by the Census Bureau. Clustered standard errors are presented in parentheses. $* * * \mathrm{p}<0.01, * * \mathrm{p}<0.05, * \mathrm{p}<0.1$.

\section{d. Main treatment effects with continuous death and loss estimates}

As we are primarily interested in how people respond to either underestimating or overestimating the death and income loss of the pandemic, we used a categorical variable that classified people as either underestimating, overestimating or having a correct estimate for both variables. For robustness, we also ran our main analysis with a continuous variable for people's estimates. The results of this test are reported in table 25 . Unsurprisingly, the results of this analysis differ from those of our main analysis and there are no significant interactions between the treatments and continuous estimates of death and income loss. This result indicates that the magnitude of respondents' estimates does not affect their change in preferences over health and wealth but rather whether these estimates over- or underestimate the impact of the pandemic. 


\begin{tabular}{lcccc} 
& \multicolumn{5}{c}{ Main treatment effects } \\
& $\begin{array}{c}\text { Down from } \\
\text { max. VoL } \\
\text { (UK) }\end{array}$ & $\begin{array}{c}\text { Up to } \\
\text { max. VoL } \\
\text { (UK) }\end{array}$ & $\begin{array}{c}\text { Down from } \\
\text { max. VoL } \\
\text { (US) }\end{array}$ & $\begin{array}{c}\text { Up to max. } \\
\text { VoL (US) }\end{array}$ \\
\hline \hline Treatment & & & & \\
\hline & 0.186 & $-1.307^{*}$ & -0.134 & 0.321 \\
Health treatment $(T 1)$ & $(0.440)$ & $(0.700)$ & $(0.561)$ & $(0.569)$ \\
\hline & $1.014^{* * *}$ & -0.282 & -0.882 & 0.528 \\
Wealth treatment $(T 2)$ & $(0.342)$ & $(0.532)$ & $(0.696)$ & $(0.566)$ \\
\hline & $-0.002^{* *}$ & $-0.000^{*}$ & -0.000 & -0.000 \\
Income Estimate & $(0.001)$ & $(0.000)$ & $(0.000)$ & $(0.000)$ \\
\hline & $-0.032^{*}$ & 0.010 & 0.000 & -0.000 \\
T2 $x$ Income Estimate & $(0.018)$ & $(0.011)$ & $(0.000)$ & $(0.000)$ \\
\hline & -0.000 & 0.000 & -0.000 & -0.000 \\
Death Estimate & $(0.000)$ & $(0.000)$ & $(0.000)$ & $(0.000)$ \\
\hline & -0.000 & -0.000 & 0.000 & 0.000 \\
T1 $x$ Death Estimate & $(0.000)$ & $(0.000)$ & $(0.000)$ & $(0.000)$ \\
\hline & $-3.605^{* * *}$ & $-3.394 * * *$ & $-3.410 * * *$ & $-3.866^{* * *}$ \\
Constant & $(0.287)$ & $(0.302)$ & $(0.420)$ & $(0.400)$ \\
\hline \hline Regional clustering & $\checkmark$ & $\checkmark$ & $\checkmark$ & $\checkmark$ \\
\hline Observations & 1,274 & 1,274 & 971 & 971 \\
\hline Pseudo R-squared & 0.030 & 0.029 & 0.014 & 0.016 \\
\hline \hline
\end{tabular}

Notes: Estimates come from a logistic regression. Regional clustering is done based on either the 12 regions of the UK, as defined by the ONS or the 50 states of the United States, as defined by the Census Bureau. Clustered standard errors are presented in parentheses. $* * * \mathrm{p}<0.01,{ }^{*} \mathrm{p}<0.05,{ }^{*} \mathrm{p}<0.1$.

\section{e. Main treatment effects with alternative coding of death and loss estimates}

As outlined in section 1c of this SM appendix, we generated the categorical over- and underestimate of death and income loss variables by using the IHME and IMF estimates at the time of surveying. A respondent's estimate is thereby categorized as correct if it falls within a range of $+/-5,000$ deaths or $+/-1 \%$ income loss, respectively, relative to the IHME and IMF estimates. An estimate below the specified range is categorized as an underestimate, an estimate above the specified range is categorized as an overestimate. In this subsection we ran our main analysis with an alternative range to test for robustness. Table 26 reports the results of the main treatment effects with interactions for a range of $+/-2,500$ deaths and $+/-0.5 \%$ average income loss. The main treatment effects hold. Additionally, the health treatment now increases the likelihood of subjects in the UK to move away from the maximum value of life post-treatment. Given that this effect does not hold in our models with the original range of death estimates, we did not include this effect in our main analysis. 


\begin{tabular}{|c|c|c|c|c|}
\hline & \multicolumn{4}{|c|}{ Main treatment effects } \\
\hline & $\begin{array}{c}\text { Down from } \\
\text { max. VoL } \\
(\mathrm{UK})\end{array}$ & $\begin{array}{l}\text { Up to } \\
\text { max. VoL } \\
\text { (UK) }\end{array}$ & $\begin{array}{l}\text { Down from } \\
\text { max. VoL } \\
\text { (US) }\end{array}$ & $\begin{array}{l}\text { Up to max. } \\
\text { VoL (US) }\end{array}$ \\
\hline \multicolumn{5}{|l|}{ Treatment } \\
\hline Health treatment (T1) & $\begin{array}{c}0.926 * * \\
(0.417)\end{array}$ & $\begin{array}{l}-0.282 \\
(1.235)\end{array}$ & $\begin{array}{c}0.215 \\
(0.493)\end{array}$ & $\begin{array}{c}0.467 \\
(0.501)\end{array}$ \\
\hline Wealth treatment (T2) & $\begin{array}{l}-0.036 \\
(0.346)\end{array}$ & $\begin{array}{l}-0.195 \\
(0.575)\end{array}$ & $\begin{array}{c}-1.341 * \\
(0.690)\end{array}$ & $\begin{array}{c}0.332 \\
(0.545)\end{array}$ \\
\hline \multicolumn{5}{|l|}{ Income Estimate } \\
\hline T2 $x$ Underestimate & $\begin{array}{c}1.076 * * * \\
(0.236)\end{array}$ & $\begin{array}{c}0.183 \\
(0.578)\end{array}$ & $\begin{array}{c}1.886 * * * \\
(0.675)\end{array}$ & $\begin{array}{c}-0.074 \\
(0.751)\end{array}$ \\
\hline T2 $x$ Overestimate & omitted & omitted & omitted & omitted \\
\hline \multicolumn{5}{|l|}{ Death Estimate } \\
\hline T1 $x$ Underestimate & $\begin{array}{c}-0.822 \\
(0.653)\end{array}$ & $\begin{array}{c}-1.940 * * * \\
(0.153)\end{array}$ & $\begin{array}{l}-0.165 \\
(0.536)\end{array}$ & $\begin{array}{l}-0.070 \\
(0.583)\end{array}$ \\
\hline T1 x Overestimate & $\begin{array}{l}-0.368 \\
(0.407)\end{array}$ & $\begin{array}{l}-0.118 \\
(1.188)\end{array}$ & omitted & omitted \\
\hline Constant & $\begin{array}{c}-3.711 * * * \\
(0.221)\end{array}$ & $\begin{array}{c}-3.608 * * * \\
(0.310)\end{array}$ & $\begin{array}{c}-3.516 * * * \\
(0.343)\end{array}$ & $\begin{array}{c}-4.001 * * * \\
(0.345)\end{array}$ \\
\hline Regional clustering & $\checkmark$ & $\checkmark$ & $\checkmark$ & $\checkmark$ \\
\hline Observations & 1,660 & 1,660 & 1,379 & 1,379 \\
\hline Pseudo R-squared & 0.020 & 0.027 & 0.027 & 0.003 \\
\hline
\end{tabular}

Notes: Estimates come from a logistic regression. Regional clustering is done based on either the 12 regions of the UK, as defined by the ONS or the 50 states of the United States, as defined by the Census Bureau. Clustered standard errors are presented in parentheses. $* * * \mathrm{p}<0.01, * * \mathrm{p}<0.05, * \mathrm{p}<0.1$.

\section{f. Average treatment effect using post-treatment data}

Due to our survey design, we were able to conduct a within-subject analysis of respondents' change from pre- to post-treatment. As a robustness check, we additionally ran our main analysis on the post-treatment data to estimate the average treatment effect (ATE) between treatment and control groups. Table 27 reports the ATE for both the US and the UK, without death and income estimates; table 28 reports the ATE including interactions with those estimates. Our treatment effects do not survive this alternative estimation, suggesting that our demographics do not capture all differences between the control and two treatment groups. Given that our within-subject analysis indirectly accounts for such differences, the results from these models (tables 4-7) are less biased than those reported in table 27 and 28. 


\begin{tabular}{|c|c|c|c|c|}
\hline & \multicolumn{4}{|c|}{ Main treatment effects } \\
\hline & $\begin{array}{l}\text { Max. VoL } \\
\text { (UK) }\end{array}$ & $\begin{array}{c}\text { Switch } \\
\text { point (UK) }\end{array}$ & $\begin{array}{l}\text { Max. VoL } \\
\text { (US) }\end{array}$ & $\begin{array}{c}\text { Switch } \\
\text { point (US) }\end{array}$ \\
\hline Treatment & & & & \\
\hline Health treatment (T1) & $\begin{array}{c}0.122 \\
(0.180)\end{array}$ & $\begin{array}{c}0.207 \\
(0.162)\end{array}$ & $\begin{array}{c}0.133 \\
(0.143)\end{array}$ & $\begin{array}{c}0.164 \\
(0.132)\end{array}$ \\
\hline Wealth treatment (T2) & $\begin{array}{l}-0.116 \\
(0.129)\end{array}$ & $\begin{array}{c}-0.001 \\
(0.100)\end{array}$ & $\begin{array}{l}-0.025 \\
(0.148)\end{array}$ & $\begin{array}{c}0.036 \\
(0.157)\end{array}$ \\
\hline Constant & $\begin{array}{c}1.183 * * \\
(0.517)\end{array}$ & - & $\begin{array}{l}-0.112 \\
(0.660)\end{array}$ & - \\
\hline Demographic Controls & $\checkmark$ & $\checkmark$ & $\checkmark$ & $\checkmark$ \\
\hline Regional clustering & $\checkmark$ & $\checkmark$ & $\checkmark$ & $\checkmark$ \\
\hline Observations & 1,222 & 1,230 & 1,282 & 1,282 \\
\hline Pseudo R-squared & 0.075 & 0.041 & 0.100 & 0.055 \\
\hline
\end{tabular}

Notes: Estimates come from a logistic regression. Regional clustering is done based on either the 12 regions of the UK, as defined by the ONS or the 50 states of the United States, as defined by the Census Bureau. Clustered standard errors are presented in parentheses. $* * * \mathrm{p}<0.01, * * \mathrm{p}<0.05, * \mathrm{p}<0.1$. 


\section{Main treatment effects}

\begin{tabular}{cccc}
$\begin{array}{c}\text { Max. VoL } \\
\text { (UK) }\end{array}$ & $\begin{array}{c}\text { Switch } \\
\text { point (UK) }\end{array}$ & $\begin{array}{c}\text { Max. VoL } \\
\text { (US) }\end{array}$ & $\begin{array}{c}\text { Switch } \\
\text { point (US) }\end{array}$ \\
\hline
\end{tabular}

\begin{tabular}{|c|c|c|c|c|}
\hline \multicolumn{5}{|l|}{ Treatment } \\
\hline Health treatment (T1) & $\begin{array}{l}0.427 * \\
(0.255)\end{array}$ & $\begin{array}{c}0.626^{* * *} \\
(0.216)\end{array}$ & $\begin{array}{l}0.342^{*} \\
(0.185)\end{array}$ & $\begin{array}{c}13.318^{* * *} * \\
(0.960)\end{array}$ \\
\hline Wealth treatment (T2) & $\begin{array}{c}-0.284 \\
(0.924)\end{array}$ & $\begin{array}{l}-0.030 \\
(0.927)\end{array}$ & $\begin{array}{c}0.017 \\
(0.163)\end{array}$ & $\begin{array}{c}14.087^{* * *} * \\
(0.685)\end{array}$ \\
\hline \multicolumn{5}{|l|}{ Income Estimate } \\
\hline T2 $x$ Underestimate & $\begin{array}{c}0.119 \\
(0.899)\end{array}$ & $\begin{array}{c}0.053 \\
(0.952)\end{array}$ & $\begin{array}{l}-0.231 \\
(0.279)\end{array}$ & $\begin{array}{c}-14.178 * * * \\
(0.705)\end{array}$ \\
\hline T2 $x$ Overestimate & $\begin{array}{c}0.203 \\
(0.916)\end{array}$ & $\begin{array}{c}0.032 \\
(0.912)\end{array}$ & omitted & $\begin{array}{c}-14.019 \text { *** } \\
(0.704)\end{array}$ \\
\hline \multicolumn{5}{|l|}{ Death Estimate } \\
\hline T1 $x$ Underestimate & $\begin{array}{c}-0.313 \\
(0.416)\end{array}$ & $\begin{array}{l}-0.499 \\
(0.340)\end{array}$ & $\begin{array}{c}-0.445^{* *} \\
(0.207)\end{array}$ & $\begin{array}{c}-13.426 * * * \\
(0.982)\end{array}$ \\
\hline T1 x Overestimate & $\begin{array}{c}-0.369 \\
(0.359)\end{array}$ & $\begin{array}{l}-0.407 \\
(0.292)\end{array}$ & omitted & $\begin{array}{c}-12.902^{* * *} \\
(1.010)\end{array}$ \\
\hline Constant & $\begin{array}{c}1.219^{* *} \\
(0.513)\end{array}$ & - & $\begin{array}{l}-0.151 \\
(0.656) \\
\end{array}$ & - \\
\hline Demographic Controls & $\checkmark$ & $\checkmark$ & $\checkmark$ & $\checkmark$ \\
\hline Regional clustering & $\checkmark$ & $\checkmark$ & $\checkmark$ & $\checkmark$ \\
\hline Observations & 1,219 & 1,227 & 1,272 & 1,276 \\
\hline Pseudo R-squared & 0.075 & 0.041 & 0.104 & 0.058 \\
\hline
\end{tabular}

Notes: Estimates come from a logistic regression. Regional clustering is done based on either the 12 regions of the UK, as defined by the ONS or the 50 states of the United States, as defined by the Census Bureau. Clustered standard errors are presented in parentheses. $* * * \mathrm{p}<0.01, * * \mathrm{p}<0.05, * \mathrm{p}<0.1$.

\section{Survey instrument}

\section{a. United Kingdom}

\section{PART I - Preference elicitation}

When the restrictions on personal movement are increased, coronavirus spreads more slowly and so causes less loss of life because there is less peak pressure on the healthcare system. However, increasing the restrictions on personal movement also tends to disrupt and lower economic activity and this is associated with loss of income and jobs and some psychological and health costs.

It is difficult to put numbers on these. Nevertheless, we present 8 decisions below and ask you in each case to choose between two options. Each option has a combination of 'lives lost per 1 
million of the population through Covid-19 over the next 3 months' and 'the average loss of household income due to measures to prevent transmission of Covid-19 over the next 3 months'. In each of the 8 decisions, click on the option that you think has the best combination.

\begin{tabular}{|l|l|l|l|l|}
\cline { 2 - 5 } \multicolumn{1}{c|}{} & $\begin{array}{l}\text { Lives lost per 1 } \\
\text { million of } \\
\text { population }\end{array}$ & $\begin{array}{l}\text { Average loss of } \\
\text { disposable } \\
\text { household } \\
\text { income }\end{array}$ & $\begin{array}{l}\text { Lives lost per 1 } \\
\text { million of } \\
\text { population }\end{array}$ & $\begin{array}{l}\text { Average loss of } \\
\text { disposable } \\
\text { household } \\
\text { income }\end{array}$ \\
\hline Decision 1 & 445 & $£ 2700$ & 460 & $£ 2750$ \\
\hline Decision 2 & 412 & $£ 2500$ & 431 & $£ 2420$ \\
\hline Decision 3 & 383 & $£ 2300$ & 393 & $£ 2200$ \\
\hline Decision 4 & 360 & $£ 2150$ & 367 & $£ 2020$ \\
\hline Decision 5 & 300 & $£ 2000$ & 305 & $£ 1850$ \\
\hline Decision 6 & 240 & $£ 1900$ & 243 & $£ 1750$ \\
\hline Decision 7 & 230 & $£ 1800$ & 232 & $£ 1640$ \\
\hline Decision 8 & 210 & $£ 1550$ & 210 & $£ 1450$ \\
\hline
\end{tabular}

\section{PART II - Pre-treatment questions}

\section{Perception}

Please answer the following questions about the spread of the coronavirus Covid-19.

1. How serious do you think Covid-19 is compared to the seasonal flu?

- Not at all serious

- Not very serious

- Fairly serious

- Very serious

- Don't know

2. How concerned are you for you and your family about Covid-19?

- Not at all concerned

- Not very concerned

- Fairly concerned

- Very concerned

- Don't know

3. How likely are you to follow the government's guidance for reducing the spread of Covid-19?

- Very unlikely

- Fairly unlikely

- Neither likely nor unlikely

- Fairly likely

- Very likely

- Don't know 


\section{Knowledge}

1. How many people in the UK would you estimate will die in total due to coronavirus?

2. By what percentage would you estimate average income in the UK will be lower in 2020 as compared to 2019 ?

\section{PART III: Treatment}

\section{Subjects now divide into 3 groups}

Control group: listens to music

Treatment 1: Covid-19 information

The Washington-based Institute for Health Metrics and Evaluation (IHME) predicts that - with the current government guidance in place - about 23,791 people in the UK will have died due to the coronavirus by August 4. This means that the number of Covid-19 deaths per one million people would be 357 .

Please answer the following questions about the spread of the coronavirus Covid-19.

1. How serious do you think Covid-19 is compared to the seasonal flu?

- Not at all serious

- Not very serious

- Fairly serious

- Very serious

- Don't know

2. How concerned are you for you and your family about Covid-19?

- Not at all concerned

- Not very concerned

- Fairly concerned

- Very concerned

- Don't know

3. How likely are you to follow the government's guidance for reducing the spread of Covid-19?

- Very unlikely

- Fairly unlikely

- Neither likely nor unlikely

- Fairly likely

- Very likely

- Don't know

Treatment 2: Income loss information

The International Monetary Fund (IMF) expects the UK economy to shrink by $6.5 \%$ in 2020 compared with 2019. This estimated loss of $6.5 \%$ equates to a loss of around $£ 2154$ per person in 2020 compared with 2019. 
Please answer the following questions about the spread of the coronavirus Covid-19.

1. How serious do you think Covid-19 is compared to the seasonal flu?

- Not at all serious

- Not very serious

- Fairly serious

- Very serious

- Don't know

2. How concerned are you for you and your family about Covid-19?

- Not at all concerned

- Not very concerned

- Fairly concerned

- Very concerned

- Don't know

3. How likely are you to follow the government's guidance for reducing the spread of Covid-19?

- Very unlikely

- Fairly unlikely

- Neither likely nor unlikely

- Fairly likely

- Very likely

- Don't know

PART IV: Repeat of preference elicitation

PART V: Demographic and attitudinal questions

D1. Which area of the United Kingdom do you live in?

- England

- Scotland

- Wales

- Northern Ireland

D2. What is your postcode sector?

This is the first part of your postcode (the postcode area) and the first digit of the second part of the postcode (the inward code)

[Open]

D3. To which of these groups do you consider you belong?

- White British

- Any other white background

- White and Black Caribbean 
- White and Black African

- White and Asian

- Any other mixed background

- Indian

- Pakistani

- Bangladeshi

- Chinese

- Any other Asian background

- Black Caribbean

- Black African

- Any other black background

- Other ethnic group

- Prefer not to answer

D4. What is your household income before tax?

- Under $£ 10,000$

- $£ 10,000-£ 20,000$

- $£ 20,001-£ 30,000$

- $£ 30,001-£ 40,000$

- $£ 40,001-£ 50,000$

- $£ 50,001-£ 60,000$

- $£ 60,001-£ 80,000$

- $£ 80,001-£ 100,000$

- $£ 100,001-£ 150,000$

- Above $£ 150,000$

- Don't know

- Prefer not to answer

D5. Which party do you feel closest to?

- Conservative

- Labour

- Liberal Democrat

- Scottish National Party (SNP)

- Plaid Cymru

- The Brexit Party

- Green Party

- United Kingdom Independence Party (UKIP)

- Democratic Unionist Party

- Sinn Féin

- Social Democratic and Labour Party (SDLP)

- Alliance Party

- Ulster Unionist Party

- Other

- Don't know 
D6. Thinking about the 2016 Brexit referendum, to your best recollection, which side did you vote for, 'Leave' or 'Remain'?

- Leave

- Remain

- Didn't vote

- Don't know

- Prefer not to say

D7. In politics people sometimes talk of left and right. Where would you place yourself on the following scale?

Left Right Don't know

\begin{tabular}{|l|l|l|l|l|l|l|l|l|l|l|}
0 & 1 & 2 & 3 & 4 & 5 & 6 & 7 & 8 & 9 & 10 \\
\hline
\end{tabular}

D8. Some people feel that government should make much greater efforts to make people's incomes more equal. Other people feel that government should be much less concerned about how equal people's incomes are. Where would you place yourself on this scale?

Try to make incomes equal Be less concerned about equal incomes

Don't know

\begin{tabular}{|l|l|l|l|l|l|l|l|l|l|l|}
\hline 0 & 1 & 2 & 3 & 4 & 5 & 6 & 7 & 8 & 9 & 10 \\
\hline
\end{tabular}

D9. Some people think that society would be a better place if people had more respect for authority. Other people think society would be a better place if people questioned authority more often. Where would you place yourself on this scale?

Respect authority

Question authority

Don't know

\begin{tabular}{|l|l|l|l|l|l|l|l|l|l|l|}
0 & 1 & 2 & 3 & 4 & 5 & 6 & 7 & 8 & 9 & 10 \\
\hline
\end{tabular}

D10. During the last seven days, on average how much time (if any) have you spent per day following the news?

- None, no time at all

- Less than $1 / 2$ hour

- $\quad 1 / 2$ hour to 1 hour

- 1 to 2 hours

- More than 2 hours

- Don't know

D11. Generally speaking, would you say that most people can be trusted, or that you can't be too careful in dealing with people?

- Most people can be trusted

- Can't be too careful

- Don't know 
D12. How much of the time do you think you can trust the Westminster government to do what is right?

- Hardly ever

- Some of the time

- Most of the time

- Just about always

- Don't know

D13. Which of these best describes what you were doing last week?

- Working full time (30 or more hours per week)

- Working part time (8-29 hours a week)

- Working part time (less than 8 hours a week)

- On furlough (temporary leave)

- Unemployed and looking for work

- Full time university student

- Other full time student

- Retired

- Not in paid work for any other reason

- Other

For those who choose options 1-4 (including furlough) on previous question:

D1301. Are you an employee or self-employed/an independent contractor?

- An employee on a permanent contract

- An employee on a temporary contract

- Self-employed/an independent contractor

- Don't know

D14. What is your highest level of educational attainment?

- Higher Education and above

- Secondary education

- Primary education

- No formal education

\section{D15. Do you have a religious affiliation?}

- No, I do not regard myself as belonging to a religion

- Yes -Church of England/Anglican/Episcopalian

- Yes -Roman Catholic

- Yes -Presbyterian/Church of Scotland

- Yes-Methodist

- Yes -Baptist

- Yes-United Reformed Church

- Yes-Free Presbyterian

- Yes-Brethren

- Yes-Judaism 
- Yes -Hinduism

- Yes -Islam

- Yes-Sikhism

- Yes-Buddhism

- Yes-Other

- Yes -Orthodox Christian

- Yes -Pentecostal

- Yes -Evangelical -independent/non-denominational

- Prefer not to say

D16. Apart from such special occasions such as weddings, funerals and baptisms, how often do you attend services or meetings connected with your religion?

- Less often than once a year

- Less often but at least once a year

- Less often but at least twice a year

- Less often but at least once a month

- Less often but at least once in two weeks

- Once a week or more

- Varies too much to say

- I am not religious

- Don't know

D17. During the next months, how likely or unlikely is it that you will not have enough money to cover your day to day living costs?

- Very unlikely

- Fairly unlikely

- Neither likely nor unlikely

- Fairly likely

- Very likely

- Don't know

D18. Thinking about the past month, did you, as a result of the Covid-19 pandemic, earn less, about the same or more money than usual?

- Less than usual

- About the same

- More than usual

- Don't know

D19. How healthy have you felt in the last weeks?

Not healthy at all Very healthy Don't know

\begin{tabular}{|l|l|l|l|l|l|l|l|l|l|l|}
\hline 0 & 1 & 2 & 3 & 4 & 5 & 6 & 7 & 8 & 9 & 10 \\
\hline
\end{tabular}


D20. According to UK government guidelines, those above the age of 70 and/or those with underlying health conditions are at an increased risk from Covid-19. Do you consider yourself to be in this group?

- Yes

- No

- Don't know

- Prefer not to say

D21. How likely or unlikely do you think it is that you have contracted the coronavirus?

- Very unlikely

- Fairly unlikely

- Fairly likely

- Very likely

- Don't know

D22. Please tell us, in general, how willing or unwilling you are to take risks. Please use a scale from 0 to 10, where 0 means "completely unwilling to take risks" and a 10 means you are "very willing to take risks". You can also use any number between 0 and 10 to indicate where you fall on the scale.

\begin{tabular}{|l|l|l|l|l|l|l|l|l|l|l|}
\hline 0 & 1 & 2 & 3 & 4 & 5 & 6 & 7 & 8 & 9 & 10 \\
\hline
\end{tabular}

D23. Are you generally an impatient person, or someone who always shows great patience? Please use a scale from 0 to 10 where 0 means "very impatient" and a $\mathbf{1 0}$ means you are "very patient". You can also use any number between 0 and 10 to indicate where you fall on the scale.

\begin{tabular}{|l|l|l|l|l|l|l|l|l|l|l|}
\hline 0 & 1 & 2 & 3 & 4 & 5 & 6 & 7 & 8 & 9 & 10 \\
\hline
\end{tabular}

D24. Imagine you won 1,000 pounds in a lottery. Considering your current situation, how much would you donate to charity?

[Open]

\section{b. United States}

\section{PART I - Preference elicitation}

When the restrictions on personal movement are increased, coronavirus spreads more slowly and so causes less loss of life because there is less peak pressure on the healthcare system. However, increasing the restrictions on personal movement also tends to disrupt and lower economic activity and this is associated with loss of income and jobs and some psychological and health costs.

It is difficult to put numbers on these effects. Nevertheless, we present 8 decisions below and ask you in each case to choose between two options. Each option has a combination of 'lives 
lost per 1 million of the population through Covid-19 over the next 3 months' and 'the average loss of household income due to measures to prevent transmission of Covid-19 over the next 3 months'. In each of the 8 decisions, click on the option that you think has the best combination.

\begin{tabular}{|l|l|l|l|l|}
\cline { 2 - 5 } \multicolumn{1}{c|}{} & $\begin{array}{l}\text { Lives lost per 1 } \\
\text { million of } \\
\text { population }\end{array}$ & $\begin{array}{l}\text { Average loss of } \\
\text { disposable } \\
\text { household } \\
\text { income }\end{array}$ & $\begin{array}{l}\text { Lives lost per 1 } \\
\text { million of } \\
\text { population }\end{array}$ & $\begin{array}{l}\text { Average loss of } \\
\text { disposable } \\
\text { household } \\
\text { income }\end{array}$ \\
\hline Decision 1 & 320 & $\$ 4000$ & 335 & $\$ 4150$ \\
\hline Decision 2 & 310 & $\$ 3850$ & 325 & $\$ 3740$ \\
\hline Decision 3 & 247 & $\$ 3670$ & 256 & $\$ 3500$ \\
\hline Decision 4 & 213 & $\$ 3500$ & 219 & $\$ 3300$ \\
\hline Decision 5 & 200 & $\$ 3300$ & 204 & $\$ 3100$ \\
\hline Decision 6 & 188 & $£ 3120$ & 192 & $\$ 2820$ \\
\hline Decision 7 & 177 & $\$ 2350$ & 180 & $\$ 2000$ \\
\hline Decision 8 & 165 & $\$ 1950$ & 165 & $\$ 1800$ \\
\hline
\end{tabular}

\section{PART II - Pre-treatment questions}

\section{Perception}

Please answer the following questions about the spread of the coronavirus Covid-19.

1. How serious do you think Covid-19 is compared to the seasonal flu?

- Not at all serious

- Not very serious

- Fairly serious

- Very serious

- Don't know

2. How concerned are you for you and your family about Covid-19?

- Not at all concerned

- Not very concerned

- Fairly concerned

- Very concerned

- Don't know

3. How likely are you to follow the government's guidance for reducing the spread of Covid-19?

- Very unlikely

- Fairly unlikely

- Neither likely nor unlikely

- Fairly likely

- Very likely

- Don't know 


\section{Knowledge}

1. How many people in the US would you estimate will die in total due to coronavirus?

2. By what percentage would you estimate average income in the US will be lower in 2020 as compared to 2019 ?

\section{PART III: Treatment}

\section{Subjects now divide into 3 groups}

Control: they listen to music

Treatment 1: Covid-19 information

The Washington-based Institute for Health Metrics and Evaluation (IHME) predicts that - with the current government guidance in place - about 68,841 people in the US will have died due to the coronavirus by August 4. This means that the number of Covid-19 deaths per one million people would be 210 .

Please answer the following questions about the spread of the coronavirus Covid-19.

1. How serious do you think Covid-19 is compared to the seasonal flu?

- Not at all serious

- Not very serious

- Fairly serious

- Very serious

- Don't know

2. How concerned are you for you and your family about Covid-19?

- Not at all concerned

- Not very concerned

- Fairly concerned

- Very concerned

- Don't know

3. How likely are you to follow the government's guidance for reducing the spread of Covid-19?

- Very unlikely

- Fairly unlikely

- Neither likely nor unlikely

- Fairly likely

- Very likely

- Don’t know

Treatment 2: Income loss information

The International Monetary Fund (IMF) expects the US economy to shrink by $5.9 \%$ in 2020 compared with 2019. This estimated loss of 5.9\% equates to a loss of around $\$ 3848$ per person in 2020 compared with 2019. 
Please answer the following questions about the spread of the coronavirus Covid-19.

1. How serious do you think Covid-19 is compared to the seasonal flu?

- Not at all serious

- Not very serious

- Fairly serious

- Very serious

- Don't know

2. How concerned are you for you and your family about Covid-19?

- Not at all concerned

- Not very concerned

- Fairly concerned

- Very concerned

- Don't know

3. How likely are you to follow the government's guidance for reducing the spread of Covid-19?

- Very unlikely

- Fairly unlikely

- Neither likely nor unlikely

- Fairly likely

- Very likely

- Don't know

PART IV: Repeat of preference elicitation

\section{PART V: Demographic and attitudinal questions}

D1. Which US state do you live in?

1. Alabama

2. Alaska

3. Arizona

4. Arkansas

5. California

6. Colorado

7. Connecticut

8. Delaware

9. Florida

10. Georgia

11. Hawaii

12. Idaho

13. Illinois

14. Indiana

15. Iowa

16. Kansas

17. Kentucky 
18. Louisiana

19. Maine

20. Maryland

21. Massachusetts

22. Michigan

23. Minnesota

24. Mississippi

25. Missouri

26. Montana

27. Nebraska

28. Nevada

29. New Hampshire

30. New Jersey

31. New Mexico

32. New York

33. North Carolina

34. North Dakota

35. Ohio

36. Oklahoma

37. Oregon

38. Pennsylvania

39. Rhode Island

40. South Carolina

41. South Dakota

42. Tennessee

43. Texas

44. Utah

45. Vermont

46. Virginia

47. Washington

48. West Virginia

49. Wisconsin

50. Wyoming

51. District of Columbia

D2. In which county do you live?

$$
\text { [Open] }
$$

D3. Are you Spanish, Hispanic, or Latino?

- Yes

- No

D4. Below you will find a list of five race categories. Please choose one or more races that you consider yourself to be:

D401. White [yes/no]

D402. Black or African-American [yes/no]

D403. American Indian or Alaska Native [yes/no]

D404. Asian [yes/no] 
D405. Native Hawaiian or other Pacific Islander [yes/no]

Other group

Prefer not to answer

D5. What is your household income before tax?

- Under $\$ 10,000$

- $\$ 10,000-\$ 20,000$

- $\$ 20,001-\$ 30,000$

- $\$ 30,001-\$ 40,000$

- $\$ 40,001-\$ 50,000$

- $\$ 50,001-\$ 60,000$

- $\$ 60,001-\$ 80,000$

- $\$ 80,001-\$ 100,000$

- $\$ 100,001-\$ 150,000$

- $\$ 150,001-\$ 200,000$

- Above \$200,000

- Don't know

- Prefer not to answer

D6. Which party do you feel closest to?

- Democratic Party

- Republican Party

- Other

- Don't know

D7. Thinking about the 2016 Presidential Election, to your best recollection, whom did you vote for?

- Hillary Clinton

- Donald Trump

- Didn't vote

- Don't know

- Prefer not to say

D8. In politics people sometimes talk of left and right. Where would you place yourself on the following scale?

Left Right Don't know

\begin{tabular}{|l|l|l|l|l|l|l|l|l|l|l|}
0 & 1 & 2 & 3 & 4 & 5 & 6 & 7 & 8 & 9 & 10 \\
\hline
\end{tabular}

D9. Some people feel that government should make much greater efforts to make people's incomes more equal. Other people feel that government should be much less concerned about how equal people's incomes are. Where would you place yourself on this scale?

Try to make incomes equal Be less concerned about equal incomes

Don't know

\begin{tabular}{|l|l|l|l|l|l|l|l|l|l|l|}
0 & 1 & 2 & 3 & 4 & 5 & 6 & 7 & 8 & 9 & 10 \\
\hline
\end{tabular}


D10. Some people think that society would be a better place if people had more respect for authority. Other people think society would be a better place if people questioned authority more often. Where would you place yourself on this scale?

Respect authority

Question authority

Don't know

\begin{tabular}{|l|l|l|l|l|l|l|l|l|l|l|}
0 & 1 & 2 & 3 & 4 & 5 & 6 & 7 & 8 & 9 & 10 \\
\hline
\end{tabular}

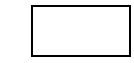

D11. During the last seven days, on average how much time (if any) have you spent per day following the news?

- None, no time at all

- Less than $1 / 2$ hour

- $\quad 1 / 2$ hour to 1 hour

- 1 to 2 hours

- More than 2 hours

- Don't know

D12. Generally speaking, would you say that most people can be trusted, or that you can't be too careful in dealing with people?

- Most people can be trusted

- Can't be too careful

- Don't know

D13. How much of the time do you think you can trust the federal government in Washington to do what is right?

- Hardly ever

- Some of the time

- Most of the time

- Just about always

- Don't know

D14. Which of these best describes what you were doing last week?

- Working full time (30 or more hours per week)

- Working part time (8-29 hours a week)

- Working part time (less than 8 hours a week)

- On furlough (temporary leave)

- Unemployed and looking for work

- Full time university student

- Other full time student

- Retired

- Not in paid work for any other reason

- Other 
For those who choose options 1-4 (including furlough) on previous question:

D1401. Are you an employee or self-employed/an independent contractor?

- An employee on a permanent contract

- An employee on a temporary contract

- Self-employed/an independent contractor

- Don't know

D15. What is your highest level of educational attainment?

- College and above

- High school

- Elementary school

- No formal education

D16. Do you have a religious affiliation?

- No, I do not regard myself as belonging to a religion

- Yes - Protestant

- Yes - Roman Catholic

- Yes - Mormon

- Yes - Other Christian

- Yes - Jewish

- Yes - Muslim

- Yes - Other non-Christian religion

- Prefer not to say

D17. Apart from such special occasions such as weddings, funerals and baptisms, how often do you attend services or meetings connected with your religion?

- Less often than once a year

- Less often but at least once a year

- Less often but at least twice a year

- Less often but at least once a month

- Less often but at least once in two weeks

- Once a week or more

- Varies too much to say

- I am not religious

- Don't know

D18. During the next months, how likely or unlikely is it that you will not have enough money to cover your day to day living costs?

- Very unlikely

- Fairly unlikely

- Neither likely nor unlikely

- Fairly likely

- Very likely

- Don't know 
D19. Thinking about the past month, did you, as a result of the Covid-19 pandemic, earn less, about the same or more money than usual?

- Less than usual

- About the same

- More than usual

- Don't know

D20. How healthy have you felt in the last weeks?

Not healthy at all Very healthy Don't know

\begin{tabular}{|l|l|l|l|l|l|l|l|l|l|l|}
\hline 0 & 1 & 2 & 3 & 4 & 5 & 6 & 7 & 8 & 9 & 10 \\
\hline
\end{tabular}

D21. According to UK government guidelines, those above the age of 70 and/or those with underlying health conditions are at an increased risk from Covid-19. Do you consider yourself to be in this group?

- Yes

- No

- Don't know

- Prefer not to say

D22. How likely or unlikely do you think it is that you have contracted the coronavirus?

- Very unlikely

- Fairly unlikely

- Fairly likely

- Very likely

- Don't know

D23. Please tell us, in general, how willing or unwilling you are to take risks. Please use a scale from 0 to 10, where 0 means "completely unwilling to take risks" and a 10 means you are "very willing to take risks". You can also use any numbers between 0 and 10 to indicate where you fall on the scale.

\begin{tabular}{|l|l|l|l|l|l|l|l|l|l|l|}
\hline 0 & 1 & 2 & 3 & 4 & 5 & 6 & 7 & 8 & 9 & 10 \\
\hline
\end{tabular}

D24. Are you generally an impatient person, or someone who always shows great patience? Please use a scale from 0 to 10 where 0 means "very impatient" and a 10 means you are "very patient". You can also use any numbers between 0 and 10 to indicate where you fall on the scale.

\begin{tabular}{|l|l|l|l|l|l|l|l|l|l|l|}
\hline 0 & 1 & 2 & 3 & 4 & 5 & 6 & 7 & 8 & 9 & 10 \\
\hline
\end{tabular}

D25. Imagine you won 1,000 dollar in a lottery. Considering your current situation, how much would you donate to charity?

[Open] 


\section{References and notes}

1. J. Dehning, J. Zierenberg, F.P. Spitzner, M. Wibral, J.P. Neto, M. Wilczek, V. Priesemann, Inferring change points in the spread of COVID-19 reveals the effectiveness of interventions. Science 10.1126/science.abb9789 (2020).

2. International Monetary Fund (IMF), "World economic outlook, April 2020: The great lockdown” (IMF, 2020); www.imf.org/en/Publications/WEO/Issues/2020/04/14/weoapril-2020.

3. T.R. Tyler, Why People Obey the Law (Yale University Press, New Haven, CT, and London, UK, 1990).

4. D.M. Kreps, A Course in Microeconomic Theory (Princeton University Press, Princeton, NJ, 1990).

5. C.A. Holt, S.K. Laury, Risk aversion and incentive effects. American Economic Review. 92, 1644-1655 (2002).

6. I. Bateman, R.T. Carson, B. Day, M. Hanemann, N. Hanley, T. Hett, M. Jones-Lee, G. Loomes, S. Mourato, E. Özdemiroglu, D. Pearce, R. Sugden, J. Swanson, Economic Valuation with Stated Preference Techniques: A Manual (Edward Elgar, Cheltenham, UK, 2002).

7. Institute for Health Metrics and Evaluation (IHME), "New COVID-19 forecasts for Europe: Italy and Spain have passed the peak of their epidemics; UK, early in its epidemic, faces a fast-mounting death toll" (IHME, 2020);

http://www.healthdata.org/news-release/new-covid-19-forecasts-europe-italy-spain-havepassed-peak-their-epidemics-uk-early-its.

8. Institute for Health Metrics and Evaluation (IHME), "New IHME COVID-19 forecasts show state-by-state peaks" (IHME, 2020); http://www.healthdata.org/news-release/ihmehold-media-briefing-4-pm-eastern-today-details-below.

9. EGAP Pre-analysis Registry, PAP number 20200416AB, https://www.egap.org/content/maximizing-effectiveness-policy-based-responses-covid19 -citizens $\% \mathrm{E} 2 \% 80 \% 99$-preferences-over-multi.

10. D. Bol, M. Giani, A. Blais, P.J. Loewen, The effect of COVID-19 lockdowns on political support: Some good news for democracy? (SocArXiv, 2020). https://osf.io/preprints/socarxiv/7hpj9/.

11. Organisation for Economic Co-operation and Development (OECD), "Mortality risk valuation in environment, health and transport policies (OECD, 2012); http://www.oecd.org/environment/mortalityriskvaluationinenvironmenthealthandtransport policies.htm.

12. US Census Bureau, "Current population survey" (US Census Bureau, 2018); https://www.census.gov/cps/data/cpstablecreator.html.

13. Office of National Statistics (ONS), "CT0486_2011 Census - Sex by age by ethnic group by economic activity - National to region and London boroughs" (ONS, 2011); https://www.ons.gov.uk/.

14. National Records of Scotland (NRS), "DC6107SC - Economic activity by sex by age" (NRS, 2011); https://www.scotlandscensus.gov.uk/ods-web/standard-outputs.html.

15. Institute for Health Metrics and Evaluation (IHME). "Projections" (IHME, 2020); https://covid19.healthdata.org/united-states-of-america. 